\title{
Hotter droughts alter resource allocation to chemical defenses in piñon pine
}

\author{
Amy M. Trowbridge ${ }^{1,2} \cdot$ Henry D. Adams $^{3} \cdot$ Adam Collins $^{4} \cdot$ Lee Turin Dickman ${ }^{4} \cdot$ Charlotte Grossiord $^{5,6}$. \\ Megan Hofland ${ }^{2} \cdot$ Shealyn Malone ${ }^{1,2} \cdot$ David K. Weaver $^{2} \cdot$ Sanna Sevanto ${ }^{4} \cdot$ Paul C. Stoy $^{2,7} \cdot$ Nate G. McDowell $^{8}$
}

Received: 10 February 2021 / Accepted: 4 October 2021 / Published online: 17 October 2021

(c) The Author(s) 2021

\begin{abstract}
Heat and drought affect plant chemical defenses and thereby plant susceptibility to pests and pathogens. Monoterpenes are of particular importance for conifers as they play critical roles in defense against bark beetles. To date, work seeking to understand the impacts of heat and drought on monoterpenes has primarily focused on young potted seedlings, leaving it unclear how older age classes that are more vulnerable to bark beetles might respond to stress. Furthermore, we lack a clear picture of what carbon resources might be prioritized to support monoterpene synthesis under drought stress. To address this, we measured needle and woody tissue monoterpene concentrations and physiological variables simultaneously from mature piñon pines (Pinus edulis) from a unique temperature and drought manipulation field experiment. While heat had no effect on total monoterpene concentrations, trees under combined heat and drought stress exhibited $\sim 85 \%$ and $35 \%$ increases in needle and woody tissue, respectively, over multiple years. Plant physiological variables like maximum photosynthesis each explained less than $10 \%$ of the variation in total monoterpenes for both tissue types while starch and glucose + fructose measured 1-month prior explained $\sim 45 \%$ and $60 \%$ of the variation in woody tissue total monoterpene concentrations. Although total monoterpenes increased under combined stress, some key monoterpenes with known roles in bark beetle ecology decreased. These shifts may make trees more favorable for bark beetle attack rather than well defended, which one might conclude if only considering total monoterpene concentrations. Our results point to cumulative and synergistic effects of heat and drought that may reprioritize carbon allocation of specific non-structural carbohydrates toward defense.
\end{abstract}

Keywords Drought $\cdot$ Heat $\cdot$ Ips confusus (piñon engraver beetle) $\cdot$ Monoterpenes $\cdot$ Non-structural carbohydrates

\section{Introduction}

Drought-induced tree mortality, alone or in conjunction with forest pests and pathogens, has changed ecosystem composition and function across the globe (Allen et al.

Communicated by Christiane Roscher.

Amy M. Trowbridge

amtrowbridge@wisc.edu

1 Department of Entomology, University of WisconsinMadison, Madison, WI 53706, USA

2 Department of Land Resources and Environmental Sciences, Montana State University, Bozeman, MT 59715, USA

3 School of the Environment, Washington State University, Pullman, WA 99164, USA

4 Earth and Environmental Sciences Division, Los Alamos National Laboratory, Los Alamos, NM 87545, USA
2010; Hartmann et al. 2018). Biotic and abiotic stressors are expected to become even more acute in the future (IPCC 2014), emphasizing the need to understand what causes trees to die. Work to date on the mechanisms underlying drought-related tree death has primarily focused on the coupled roles of reduced available carbohydrates and hydraulic conductivity (Anderegg et al. 2012; Hartmann et al. 2013;

5 Plant Ecology Research Laboratory PERL, School of Architecture, Civil and Environmental Engineering, EPFL, 1015 Lausanne, Switzerland

6 Functional Plant Ecology, Community Ecology Unit, Swiss Federal Institute for Forest, Snow and Landscape WSL, 1015 Lausanne, Switzerland

7 Department of Biological Systems Engineering, University of Wisconsin-Madison, Madison, WI 53706, USA

8 Earth Systems Science Division, Pacific Northwest National Laboratory, Richland, WA 99354, USA 
O'Brien et al. 2014; Sevanto et al. 2014; McDowell et al. 2016; Adams et al. 2017). Yet the carbon and water status of trees is also critical to the synthesis of secondary metabolites, i.e. plant chemical defenses, which in turn, influence the insect population dynamics that also cause tree mortality (Raffa et al. 2008; McDowell et al. 2011; Anderegg et al. 2015). Thus, information on how secondary metabolites change under heat and drought stress provides a critical link between tree stress physiology and the incumbent insect behavior that can ultimately result in tree death. To this end, more field studies are required to better understand the links between well-studied aspects of primary physiology (i.e., photosynthesis) and less understood components, such as non-structural carbohydrates (NSCs) and defense (Ryan et al. 2015). This is especially true considering the majority of our assumptions regarding relationships between these processes and carbon pools are primarily derived from work in young potted seedlings (e.g. Llusia and Penuelas 1998; Turtola et al. 2003; Blanch et al. 2009; Klutsch et al. 2017; Lupke et al. 2017).

Bark beetles (Coleoptera: Curculionidae) and their fungal symbionts are significant biotic disturbance agents affecting coniferous forests (Raffa et al. 2008; Bentz et al. 2010). While climate directly impacts bark beetle population dynamics, fitness is also indirectly affected by climateinduced changes in host quality, namely nutrient availability and oleoresin composition (Raffa and Berryman 1987; Byers 2007; Franceschi et al. 2005). Oleoresin is a mixture of monoterpenes, sesquiterpenes, and diterpene acids produced by trees (Keeling and Bohlmann 2006). Both biotic and abiotic stresses can shift the composition of terpenes within the oleoresin, ultimately determining whether a tree will prove resistant or susceptible to insect pests and microbial pathogens (Keefover-Ring et al. 2016; Trowbridge et al. 2016). The amount of carbon that can be allocated to components within resin depends on both recently assimilated photosynthates as well as stored NSCs (Huang et al. 2019b). Thus, environmental conditions that impact carbohydrate availability, like drought, will undoubtedly have cascading effects on oleoresin production, and in turn, tree defense against biotic agents (Christiansen et al. 1987).

Monoterpenes dominate conifer oleoresin and are of particular interest as they mediate dynamic - but dose- and composition-dependent-relationships among tree hosts, bark beetles, and beetle-associated fungal pathogens (Raffa et al. 2008; Raffa 2013). Generally, high monoterpene concentrations are toxic to bark beetles and their symbionts, as has been demonstrated for both primary aggressive bark beetles, such as mountain pine beetle (Dendroctonus ponderosae; Erbilgin et al. 2003), and secondary non-aggressive species like the North American pine engraver (Ips pini; Raffa et al. 2005). Both aggressive and non-aggressive bark beetles that rely on aggregation pheromones can also exploit low emissions of monoterpenes for their production. For example, cis-verbenol, a minor constituent of the pheromone blend of the pinyon engraver (Ips confusus) is produced through the hydroxylation of a-pinene from its host tree, which is also the case for verbenol production by D. ponderosae (Chiu et al. 2018; Fisher et al. 2021), Other monoterpenes, such as $\beta$-myrcene, may serve as pheromone synergists, but can also be toxic at high levels (Blomquist et al. 2010; Erbilgin et al. 2017). Whether involved in deterrence or aggregation, monoterpene synthesis comes at the expense of carbon that would otherwise be allocated towards processes like growth and storage (Huang et al. 2019a). Furthermore, in response to both abiotic and biotic stress, trees may rely more on NSCs as opposed to newly fixed intermediates (Sevanto and Dickman 2015; Wiley et al. 2016; Roth et al. 2018). The NSCs that are mobilized and the specific defense compounds they support is likely shaped by a combination of past biotic selective pressures and the need to maintain critical physiological functions in the face of current stresses (Cheng et al. 2007; Loreto et al. 2010). Identifying conditions under which chemical defenses are prioritized (or constrained) and trade-offs emerge is critical for calculating risk of mortality by biotic agents (Huang et al. 2020).

Our conceptual understanding of investment in plant chemical defenses has long been guided by the growth-differentiation balance hypothesis (GDBH) (Loomis 1932; Herms and Mattson 1992; Fig. 1a). The GDBH posits that moderate stress inhibits growth more strongly than it does photosynthesis such that the growth carbon sink strength is dampened and the carbon pool available for secondary metabolism, and thus $\mathrm{C}$ allocation towards secondary metabolism itself, is increased. Because drought impedes growth, one would expect an increase in NSC availability and subsequent allocation to monoterpenes as drought stress becomes more severe. There are, however, conflicting reports regarding NSC dynamics during drought (Li et al. 2018); they can decrease (Galiano et al. 2011; McDowell et al. 2013; Woodruff 2014; Dickman et al. 2015), increase (O'Brien et al. 2015), or remain unchanged (Rosas et al. 2013). Furthermore, most studies have focused on patterns of NSC allocation to belowground structures, storage and, osmoregulation (Hartmann and Trumbore 2016; Mackay et al. 2020) with little consideration for chemical defense. Despite the importance of secondary metabolites as carbon sinks, to our knowledge, no studies have experimentally tested the links between drought stress physiology, NSCs, and defense in mature conifers in situ.

Trees are becoming increasingly vulnerable to pests and pathogens under hotter droughts (Allen et al. 2015), yet the interactive effects of heat and drought on monoterpene production in mature trees is largely unknown. Monoterpene production can be quite variable in response to drought (Niinemets 2017). While increased levels of 

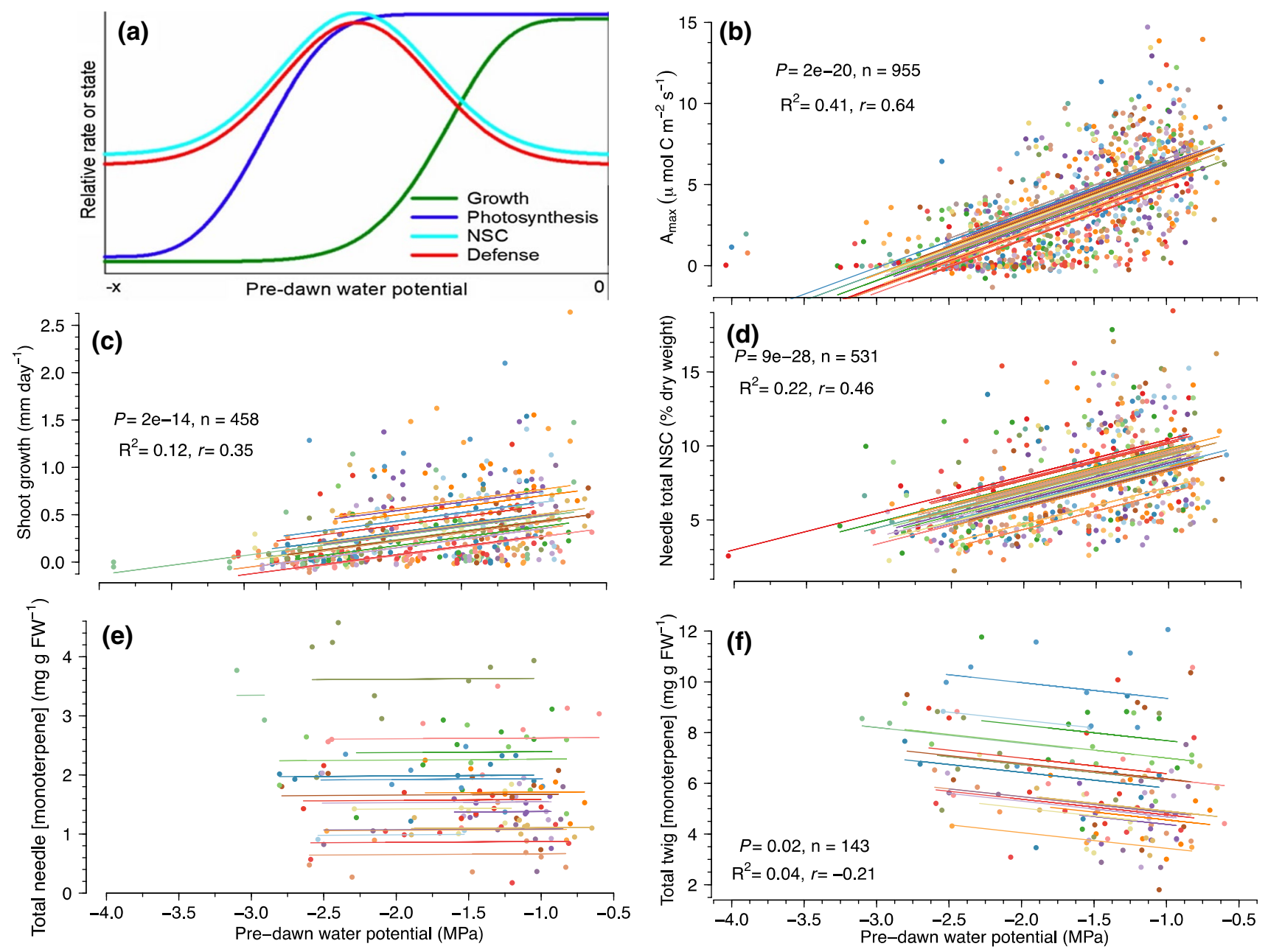

Fig. 1 Differences in relative growth rate, net assimilation rate, nonstructural carbohydrates (NSCs), and constitutive secondary metabolism across a gradient of resource availability as predicted by a the growth-differentiation balance hypothesis (modified from Fig. 1 of Herms and Mattson 1992). b Mid-day photosynthesis rate $\left(A_{\max } ;\right), \mathbf{c}$ shoot growth rate, $\mathbf{d}$ total needle NSCs, e needle total monoterpene concentrations, and f) woody tissue total monoterpene concentrations from our study are shown as a function of pre-dawn water potential.

tissue monoterpene concentrations are generally reported in response to drought (e.g., Llusia and Penuelas 1998; Turtola et al. 2003; Blanch et al. 2009; Nowak et al. 2010), these results stem primarily from young potted plants in greenhouse studies. Elevated temperature alone has also been shown to modify terpene metabolism (Penuelas and Munne-Bosch 2005). However, recent studies have provided evidence that drought can override the effects of heat in controlling monoterpene production and emissions (e.g., Trowbridge et al. 2014, 2019), but the observational nature of these studies made it impossible to tease apart the relative contribution of heat and drought. Thus, an enhanced understanding of carbon allocation to defense compounds in response to heat and drought stress, both separately and

Each set of data represent all the time points available from 2012 to 2016 for that analysis and relationships between total monoterpenes and pre-dawn water potentials are on a 1-month lag. The best-fit repeated measures regression lines are displayed along with the corresponding equation, $R^{2}$, repeated measures correlation coefficient $(r)$, $P$ value, and sample sizes $(n)$. Throughout, different colors refer to different trees

in concert, would provide crucial insight into mechanisms governing defense production in mature trees.

To elucidate some of the complex relationships between primary and secondary metabolism in situ, we assessed tree water stress status, photosynthesis rate, growth, NSCs, and constitutive monoterpene concentrations across a drought and heat stress gradient. Specifically, we sampled needle and woody tissues from mature piñon pine (Pinus edulis (Engelm.)) trees that were part of a large-scale temperature and precipitation manipulation experiment where trees were assigned to one of the following treatments: ambient conditions, heat $\left(\sim 5^{\circ} \mathrm{C}\right.$ above ambient), drought $(\sim 45 \%$ reduction in precipitation), and combined heat and drought conditions. We address the following research questions: (1) how do 
prolonged drought and heat stress, separate and combined, alter monoterpene concentrations in different tissues? (2) How do these shifts in total and individual monoterpene concentrations change in relation to primary physiological factors (e.g. growth and photosynthesis) over time? (3) What NSC pools (sucrose, glucose + fructose, starch) are potentially being mobilized to support monoterpene production? We hypothesized that, as predicted by the GDBH, monoterpene concentrations in needles and woody tissues would increase under drought stress and that increased stress/resource limitation by combined heat and drought would result in even greater concentrations. Also, in line with the GDBH, we expected that at drought levels that reduced growth but still supported relatively high rates of photosynthesis, photosynthates would in part support the increased monoterpene concentration. We anticipated that as photosynthesis declined as drought became more severe, we would observe significant relationships between monoterpenes and the soluble sugars sucrose, glucose, and fructose due to a greater reliance on the mobilization of NSCs to support monoterpene biosynthesis. Finally, we rely on previous work regarding the pinyon engraver's (Ips confusus) pheromone production and the effects of monoterpenes on aggressive and non-aggressive bark beetles to discuss how droughtinduced shifts in key monoterpenes may impact the pinyon engraver's host choice and success.

\section{Materials and methods}

\section{Study site and experimental design}

The study was performed near Los Alamos, New Mexico, USA $\left(35.49^{\circ} \mathrm{N}, 106.18^{\circ} \mathrm{W}\right.$, elevation $\left.2150 \mathrm{~m}\right)$ at the Los Alamos SUrvival-MOrtality (SUMO) experiment (Adams et al. 2015; Grossiord et al. 2017a; McDowell et al. 2019). The site is located within a piñon-juniper woodland and Juniperus monosperma (Engelm.), respectively) near the ponderosa pine (Pinus ponderosa) forest ecotone (see Adams et al. (2015) for a full description of the tree community at SUMO). Soils are Hackroy clay loam 40-80 cm above a parent material of volcanic tuff (Soil Survey Staff, Natural Resources Conservation Service, USDA, http:// websoilsurvey.nrcs.usda.gov). The local climate is semiarid (mean annual temperature $=21.1^{\circ} \mathrm{C}$ and mean annual precipitation $=401 \mathrm{~mm}$ for $1987-2016$ ) and experiences pronounced monsoon rains between July and September.

A manipulative field experiment was established in June 2012 with mature piñon trees $(>10 \mathrm{~cm}$ diameter at chest height, mean tree age $56 \pm 5$ years) assigned to one of five treatments: ambient precipitation and temperature (A), heat stress $\left(\sim+4.8{ }^{\circ} \mathrm{C} \pm 0.3{ }^{\circ} \mathrm{C}\right.$ above ambient; $\left.\mathrm{H}\right)$, reduced precipitation ( $\sim 45 \%$ rainout; $\mathrm{D})$, and both reduced precipitation and heat stress $\left(\sim+4.8{ }^{\circ} \mathrm{C}\right.$ and $\sim 45 \%$ rainout; HD). There were also chambers with temperatures regulated to match ambient conditions, but plant physiological measurements (e.g. photosynthesis, stomatal conductance, NSC (sugars and starch), respiration, shoot growth, etc.) did not differ between these treatments and the A treatment (Adams et al. 2015) so the A treatment was selected. Mature trees in the heat and combined heat and drought treatments were enclosed in transparent open-top chambers (OTCs) with temperature regulated via heating and cooling units (RJPL Package Heat Pump and Air Conditioner, Rheem Manufacturing Company, Atlanta, GA, USA). The rainout structures, composed of concave plastic troughs on a metal framework ( $1.3 \mathrm{~m}$ above the ground), were designed according to Pangle et al. (2012).

Temperature was monitored at the site and within each OTC at $1 \mathrm{~m}$ and 2/3 tree height (CS215 Temperature and Relative Humidity Probe and CR1000 data logger, Campbell Scientific, Logan, UT, USA) to set desired temperature conditions in the chambers. There were a total of 18 chambers with some chambers containing up to five trees. This setup was chosen because some trees grew in clusters and separating them to different chambers was not possible. In some cases, tree replicates for the same treatment were in the same chamber, but there were no more than three trees of the same species (Pinus edulis or Juniperus monosperma) in any of the chambers. However, for this study we measured four piñons within each treatment. The four piñons sampled within the $\mathrm{H}+\mathrm{D}$ treatment group were in different chambers, and the only trees that were in the same chamber were two $\mathrm{H}$ treatment piñons. A more detailed description of the SUMO experimental design can be found in Adams et al. (2015), Grossiord et al. (2017a), and McDowell et al. (2019).

\section{Monoterpene sample collection and chemical analysis}

Current and 1-year-old piñon pine needles and the distal $10-12 \mathrm{~cm}$ of the shoot were collected at chest height from south-facing branches of trees in the A, H, D, and HD treatments ( $n=4$ trees per treatment) across nine sampling dates from 2012 to 2016: one date in 2012 (14 November), two in 2013 (4 April and 18 September), four in 2014 (15 May, 8 July, 5 August, and 9 September), one in 2015 (31 March), and one in 2016 (24 August). Needle and woody tissue samples were immediately flash frozen and stored in liquid nitrogen prior to transport to the lab where they were stored in $\mathrm{a}-80{ }^{\circ} \mathrm{C}$ freezer before being shipped on dry ice to Montana State University for analysis. Piñon pine tissue processing and analysis followed Trowbridge et al. (2014) (see Supporting Information Methods S1 for more detail). 


\section{Water potential and leaf gas exchange}

We measured both mean predawn $\left(\psi_{\mathrm{pd}}\right)$ and midday leaf water potentials ( $n=2$ twigs per tree) for each tree within the $\mathrm{A}, \mathrm{H}, \mathrm{D}$, and HD treatments ( $n=4$ trees per treatment) using a Scholander pressure chamber (PMS Instruments, Albany, OR). Twigs were excised from sun-exposed portions on the south side of each tree before dawn and between 11:30 and 13:00 on the same days as monoterpene sample collections and monthly over the course of the experiment. Samples were stored in the dark at $20{ }^{\circ} \mathrm{C}$ until measurement within $2 \mathrm{~h}$ of collection.

We also measured mid-morning photosynthesis $\left(A_{\max }\right.$, $\left.\mu \mathrm{mol} \mathrm{m} \mathrm{s}^{-2}\right)$ and stomatal conductance $\left(g_{\mathrm{s}}, \mathrm{mol} \mathrm{m}^{-2} \mathrm{~s}^{-1}\right)$ (LI-6400 infrared gas-exchange analyzer system, Li-Cor, Lincoln, NE, USA) from one current-year or previous-year (depending on whether new needles had emerged) sunexposed shoot on the south side of each tree. Gas exchange was measured in the morning when the highest stomatal conductance could be expected and was typically measured within one day of water potential measurements. We used the $2 \times 3 \mathrm{LED}$ chamber with a reference $\mathrm{CO}_{2}$ concentration of $380 \mathrm{ppm}, 2000 \mu \mathrm{mol} \mathrm{m} \mathrm{m}^{-2} \mathrm{~s}^{-1}$ photosynthetic photon flux density (which is saturating for this species), $20{ }^{\circ} \mathrm{C}$ or $25^{\circ} \mathrm{C}$ block temperature depending on ambient temperatures, and we kept the relative humidity between 5 and $10 \%$ (which was done using the full scrub setting) to mimic typical conditions at our site for all treatments (Grossiord et al. 2017a). Measurements were recorded after steady state gas-exchange rates had been maintained for at least 2 min and chambers were sealed with Qubitac sealing (Channel Technology, Hong Kong) to prevent leakage from the spot where the branchlet enters the chamber. Gas exchange measurements were corrected for projected leaf area, which was measured using an LI-300C area meter (Li-Cor, Lincoln, NE, USA).

\section{Growth}

In 2013, we selected two or three branches on the same four piñon pines within each treatment to measure shoot extension of buds along the main (primary) axis of the branch, and also a paired side branch that diverged from the primary axis 3-5 years prior to measurement (Adams et al. 2015). At the beginning of the growing season (March), we measured bud length with a digital caliper or ruler, then returned at the end of the growing season (October or November) to measure final branch length. At the beginning of each subsequent year of measurement (2014-2016), if main axis buds were dead, damaged, or missing, we selected replacement branches such that there were always at least two measurement branches on each tree. Because shoot growth increments can be easily distinguished and dated in piñon pine, we also measured the shoot lengths of the prior three years at the time of the first branch selection in 2013. This resulted in a 7-year record of annual shoot growth, from 2010 to 2016. Additionally, in 2013 and 2014, we measured shoot extension periodically during the growing season, on average every 18 days in 2013 and every 26 days in 2014. From these measurements, we calculated daily growth rates of shoot extension assuming steady growth rate throughout the period.

\section{Non-structural carbohydrates}

Foliar and twig samples for NSC analysis were collected between 11:30 and 13:00 from the same four trees per treatment four times during each growing season (usually April, June, August, October). Samples for NSC analyses were collected concurrently with monoterpene samples for six of nine monoterpene sampling dates; the other three dates (May, July, and August of 2014) had samples for NSCs collected within one month of the monoterpene tissue samples. Once collected, samples for NSCs were frozen in liquid $\mathrm{N}_{2}$ at collection, transported to Los Alamos National Laboratory on dry ice, stored at $-70{ }^{\circ} \mathrm{C}$ until microwaved for $5 \mathrm{~min}$ at $800 \mathrm{~W}$, and then dried at $65^{\circ} \mathrm{C}$ for $48 \mathrm{~h}$. We pre-ground samples in a Wiley mill (Thomas Scientific, Swedesboro, $\mathrm{NJ}, \mathrm{USA}$ ) then ground all samples into a fine powder using a ball mill (VWR, Radnor, PA, USA). We measured soluble sugars (glucose, fructose, and sucrose) and starch concentrations following Dickman et al. (2015), which was modified from Hoch et al. (2002). We used water extraction, enzymatic starch digestion (with amyloglucosidase), and enzymatic sugar quantification (with phosphoglucose isomerase, invertase, glucose hexokinase, and glucose-6-P dehydrogenase). More details are provided in Adams et al., (2015). Comparison of NSC measurements among laboratories and protocols can be problematic (Quentin et al. 2015, Landhäusser et al. 2018), but we are confident in comparison among treatments in this study as all measurements were made in the same laboratory using the same protocol. We report concentrations as percentage of dry weight.

\section{Data analysis}

Mixed model analyses were performed using SAS statistical software 9.4 (SAS Institute, Cary, North Carolina, USA) to compare monoterpene chemistry, $A_{\max }$, and growth data between treatments. All data were confirmed to meet the assumption of normality. For individual monoterpene compounds, we performed separate single-factor ANOVAs (SAS: PROC MIXED) and the sum of all measured monoterpene concentrations for each tissue type, hereafter called 'total'. For all mixed models, we included treatment and time as the fixed factors and tree (nested in treatment) as the random factor to account for our repeated measures approach. Tukey's post hoc 
analyses were employed if main effects were significant. It is prudent to note here that the level of drought imposed on the trees did not significantly affect the needle tissue water content, and thus the fresh weight:dry weight (FW:DW) coefficient of trees among treatments (Supporting Information Fig. S1A). Ambient trees had a significantly higher FW:DW coefficient relative to trees in all other treatments, but the effect size was very low (Supporting Information Fig. S1B). Because fresh and dry weight monoterpene data for both tissue types provided the same statistical results, we present all monoterpene concentration data here on a fresh weight (FW) basis (Trowbridge et al. 2014, 2019). This also avoids introducing unnecessary error by converting all values to a dry weight using a conversion factor when chemistry was originally extracted from fresh mass.

To test correlations and linear models we used $\mathrm{R}$ version 3.5.2 (R Core Team 2018). We used repeated measures correlation analysis via the rmcorr package (Bakdash and Marusich 2017) to assess potential relationships between needle and woody tissue monoterpene concentrations (totals and individual compounds), NSCs, and what we call 'primary' physiological variables (e.g. shoot growth rate, $\psi_{p d}, A_{\max }$, $g_{s}$, midday water potential, etc.) and performed Bonferroni corrections to account for multiple pairwise comparisons. Because physiological variables and secondary chemistry were measured at different frequencies (e.g., $A_{\max }, \psi_{\mathrm{pd}}$, and NSCs were measured more frequently than monoterpenes), analyses that correlate primary physiology with secondary chemistry contain less data than those testing relationships among primary physiological variables. To explore potential lag responses between NSCs and total monoterpenes, we compared correlations using NSC data from the month in which monoterpenes were measured and also 1 and 2 months prior. We performed compositional analyses to determine differences in needle and woody tissue monoterpene composition among treatment, time, and their interaction using permutational multivariate ANOVA (Anderson et al. 2014; Oksanen et al. 2019). To do so, we used the 'vegdist' function in the 'vegan' package in R (Oksanen et al. 2019) to calculate dissimilarities among samples using the Bray-Curtis metric with tree ID as the strata to control for repeated measures on the same tree. To visualize needle and woody tissue monoterpene composition among treatment averaged over nine sample periods, we used non-metric multidimensional scaling (NMDS) and plotted the first two axes.

\section{Results}

\section{Effects of heat and drought stress on gas exchange, growth, and NSCs}

Across the sampling periods, there was a significant effect of time and the interaction of treatment and time on $A_{\max }$ $\left(F_{8,92}=33.60, P<0.0001\right.$ and $F_{24,92}=1.72, P=0.035$, respectively). Over the course of the experiment, $A_{\max }$ in target trees was markedly lower in combined heat and drought trees $\left(3.4 \pm 0.4 \mu \mathrm{mol} \mathrm{m} \mathrm{m}^{-2} \mathrm{~s}^{-1}\right)$ relative to trees in both ambient $\left(5.6 \pm 0.4 \mu \mathrm{mol} \mathrm{m}{ }^{-2} \mathrm{~s}^{-1}, P=0.002\right)$ and heat treatments $\left(4.7 \pm 0.4 \mu \mathrm{mol} \mathrm{m} \mathrm{m}^{-2} \mathrm{~s}^{-1}, P=0.02\right) . A_{\max }$ in trees experiencing drought $\left(4.1 \pm 0.4 \mu \mathrm{mol} \mathrm{m} \mathrm{m}^{-2} \mathrm{~s}^{-1}\right)$ was no different from combined heat and drought trees and, while lower than ambient, were not different from heated trees alone. As expected, $A_{\max }$ was positively correlated with predawn leaf water potential (Fig. 1b), meaning that assimilation was reduced with increasing drought stress.

Primary shoot growth rate $\left(\mathrm{mm} \mathrm{day}^{-1}\right)$ was positively correlated with $\psi_{\mathrm{pd}}\left(r=0.35, R^{2}=0.12, n=458, P<0.0001\right)$ meaning it decreased with increasing drought stress (Fig. 1c). The effect of year on annual growth was significant $\left(F_{6,66}=25.89, P<0.0001\right)$, and while there was no treatment effect, there was a significant treatment $\times$ year interaction $\left(F_{18,66}=2.70, P=0.0018\right)$ (Supporting Information Fig. S2). Within years, there were significant differences in annual primary growth by treatment in 2013 and 2015 where the only differences were reduced growth in heat, drought, and combined heat and drought trees relative to controls (2013: $F_{3,11}=8.70, P=0.003$ and 2015: $\left.F_{3,11}=3.92, P=0.04\right)$; Supporting Information Fig. S2).

Total NSCs in needles were positively correlated with $\psi_{\text {pd }}\left(r=0.46, R^{2}=0.22, P<0.0001, n=531\right.$, Fig. 1 d $)$, driven primarily by positive correlations with needle starch ( $r=0.44, R^{2}=0.19, P<0.0001, n=531$, Table 1$)$. There was no correlation between total twig NSCs and $\psi_{\text {pd }}$ (Table 1) despite negative correlations with twig sucrose $(r=-0.27$, $\left.R^{2}=0.07, P<0.0001, n=531\right)$ and twig glucose + fructose $\left(r=-0.33, R^{2}=0.11, P<0.0001, n=531\right.$, Table 1). In both tissues, total monoterpene concentrations were uncorrelated (needles) or poorly correlated (twigs) with $\psi_{\text {pd }}$ (Fig. 1e and f), which explained only $4 \%$ of the variation.

\section{Effects of heat and drought on total monoterpene concentrations}

Sixteen monoterpenes were identified in the needle and wood samples: $(-)-\alpha$-pinene, $(+)-\alpha$-pinene, tricyclene, $(-)$-camphene, $(+)$-camphene, $\beta$-myrcene, $(+)$ - $\beta$-pinene, $(-)$ - $\beta$-pinene, $\delta$-3-carene, $S$ - $(-)$-limonene, $\mathrm{R}-(+)$-limonene, 
Table 1 Correlations between non-structural carbohydrates and pre-dawn water potential from Pinus edulis twigs

\begin{tabular}{|c|c|c|c|c|}
\hline Tree organ & Total NSCs & Starch & Sucrose & Glucose + fructose \\
\hline Leaf & $0.46\left(<2.2 \times 10^{-16}\right)$ & $0.44\left(<2.2 \times 10^{-16}\right)$ & $0.10(0.019)$ & $0.11(0.011)$ \\
\hline Twig & $-0.03(0.49)$ & $0.11(0.013)$ & $-0.27\left(7 \times 10^{-10}\right)$ & $-0.33\left(1 \times 10^{-14}\right)$ \\
\hline Bole & $-0.35(0.0006)$ & $-0.03(0.77)$ & $-0.57\left(3 \times 10^{-9}\right)$ & $-0.66\left(1 \times 10^{-12}\right)$ \\
\hline Root & $-0.25(0.07)$ & $0.019(0.89)$ & $-0.50(0.0001)$ & $-0.61\left(1 \times 10^{-6}\right)$ \\
\hline
\end{tabular}

Repeated measures $r$ correlation coefficient ( $P$ value) is displayed and significant correlations after applying the Bonferroni correction for multiple comparisons $(\alpha<0.0031)$ are indicated in bold. Negative correlation coefficients represent increasing values of NSCs with increasing drought stress (more negative pre-dawn water potential values) while positive coefficients represent decreasing values of NSCs with increased drought stress

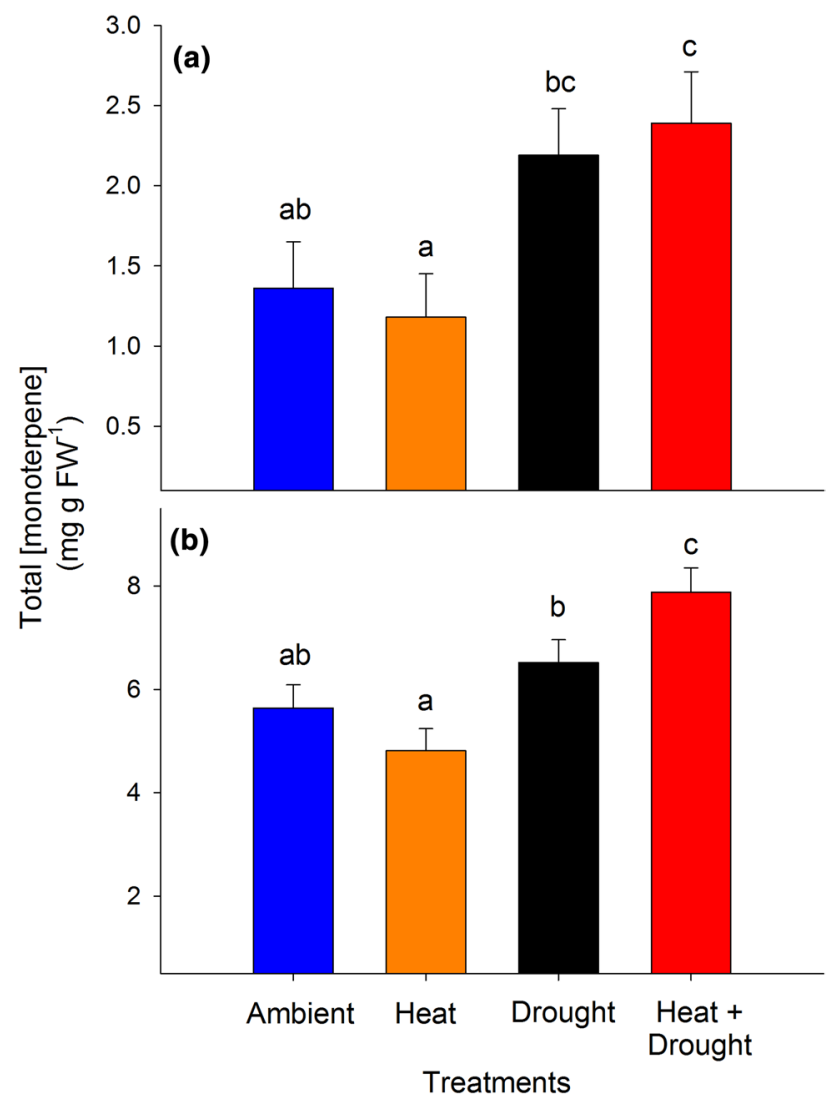

Fig. 2 Total monoterpene compound concentrations (mg g FW-1) in a Pinus edulis needles and $\mathbf{b}$ woody tissue across the four treatments averaged over nine sampling periods from 2012 to 2016. Bars are means \pm SEM and significant differences between treatments is expressed using differing lowercase letters $(a<0.05)$

$\beta$-ocimene, $\beta$-phellandrene, $\gamma$-terpinene, and terpinolene, as well as bornyl acetate $\left(\mathrm{C}_{12} \mathrm{H}_{20} \mathrm{O}_{2}\right)$, a monoterpene ester. Tricyclene was only identified in needle samples while $\beta$-ocimene and (+)- $\beta$-pinene were only identified in samples from woody tissues. Hereafter, "total monoterpenes" and "total monoterpene concentrations" are used to represent the sum of all the aforementioned compounds present in each tissue type.
Total monoterpenes in trees experiencing combined heat and drought were nearly $85 \%$ higher in needles (Fig. 2a) and $\sim 35 \%$ higher in woody tissues (Fig. $2 b$ ) relative to trees in the ambient (needles: $P=0.03$ and woody tissue: $P=0.02$ ) and heat stress (needles: $P=0.01$ and woody tissue: $P=0.0015$ ) treatment groups. In both tissues, trees in the drought treatment alone exhibited higher total needle monoterpene concentrations relative to trees from the heat treatment group ( $P=0.02$; Fig. 2$)$, while monoterpene levels in the heat trees were not different from trees exposed to ambient conditions. Unlike in the needles, woody tissue monoterpene concentrations in the combined heat and drought trees were higher than those in the drought alone treatment $(P=0.05)$. These trends were the same when concentrations were analyzed on a dry weight basis (Supporting Information Fig. S3). In both tissues, treatment and time had significant effects on total monoterpenes (needles: Fig. 3a, treatment: $F_{3,16}=4.13, P=0.02$; time: $F_{8,90}=5.52$, $P<0.0001$ and woody tissue: Fig. 3b, treatment: $F_{3,15}=8.38$, $P=0.002$; time: $\left.F_{8,94}=7.17, P<0.0001\right)$. There was also a treatment $\times$ time interaction for total concentrations in the woody tissue (Fig. 3b, treatment $\times$ time: $F_{24,94}=2.15$, $P=0.005)$. The timing of treatment effects on total monoterpenes, however, differed between tissue types. Responses in the needles were evident upon first measurement (Fig. 3a), where concentrations in the drought and the combined heat and drought trees remained elevated relative to ambient trees until 2015. In contrast, differences between the drought and combined heat and drought treatments relative to ambient were not apparent within woody tissues for approximately one year following the initiation of the treatments (Fig. 3b).

\section{Relationships between total monoterpenes and physiological variables}

Total monoterpenes in the leaf tissue were not correlated to mid-day water potential, $A_{\max }, g_{\mathrm{s}}$, or primary shoot growth rates (data not shown for mid-day water potential, $A_{\max }, g_{\mathrm{s}}$, but see Fig. 4 a for shoot growth rate). Unlike the leaf tissue, however, total monoterpenes in the woody tissue were inversely correlated to primary shoot growth rate, which 


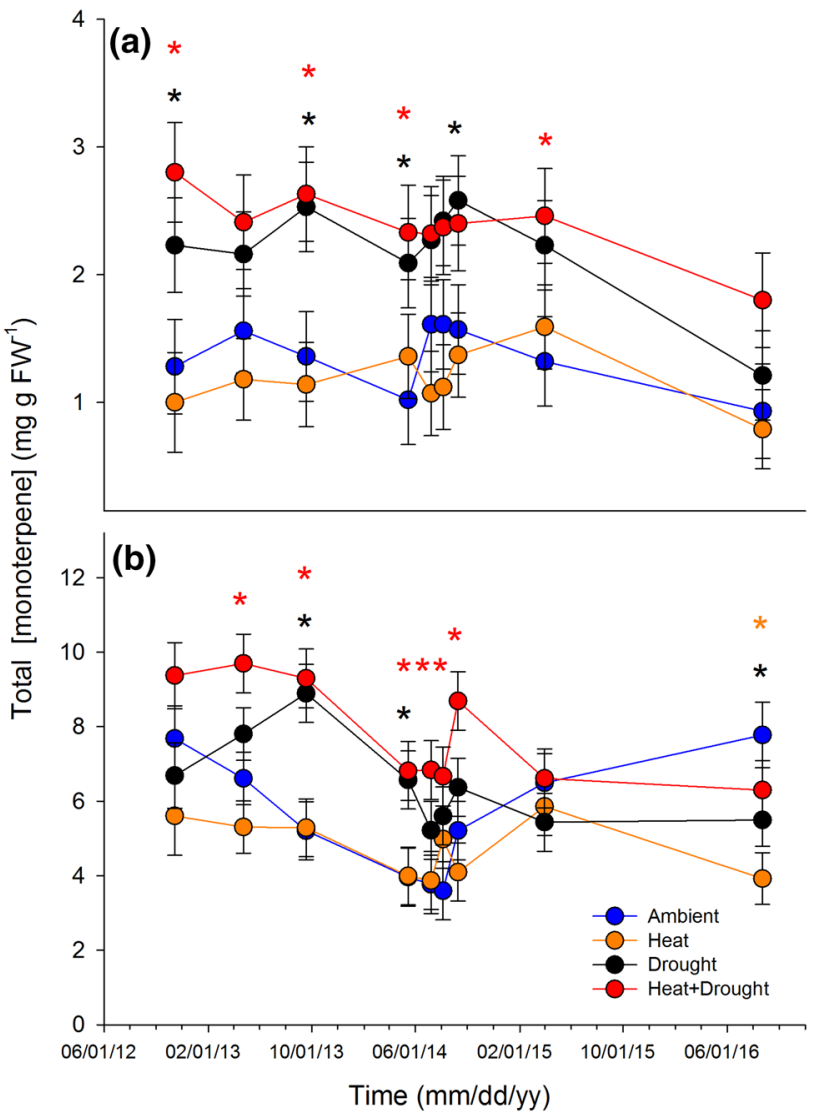

Fig. 3 Time series data representing means $( \pm$ SEM) of total monoterpene concentrations ( $\mathrm{mg} \mathrm{g} \mathrm{FW}^{-1}$ ) a needles and $\mathbf{b}$ woody tissue for Pinus edulis exposed to the four treatments across nine sampling dates from 2012 to 2016 . Totals were calculated by summing all identified monoterpenes for each tree ( $n=14$ for needle tissue; $n=16$ for woody tissue) within each treatment $(n=4)$ during each sampling period. Different colored asterisks represent a significant difference from ambient $(a<0.05)$ for that treatment

explained $11 \%$ of the variation (Fig. 4b). Total monoterpenes in the needles exhibited a negative correlation with starch as well as total NSCs measured that same month $(r=-0.55$, $R^{2}=0.31, P=0.0007, n=53$, Fig. 5a, Table 2) and were not correlated to other NSCs at any time point (Table 2). In contrast, total monoterpenes in the woody tissue were negatively correlated with starch from the previous month $(r=-0.66$, $R^{2}=0.44, P=<0.0001, n=48$, Fig. 5b, Table 2) and positively correlated with the sum of glucose and fructose from the previous month $\left(r=0.78, \mathrm{R}^{2}=0.61, P<0.0001, n=50\right.$, Fig. 5c, Table 2); each variable explained $44 \%$ and $61 \%$ of the variation, respectively.

\section{Effects of heat and drought on monoterpene composition and individual compounds}

In the ambient treatment, (-)-a-pinene, $(+)$ - $a$-pinene, $\beta$-phellandrene, and (-)- $\beta$-pinene were the four most

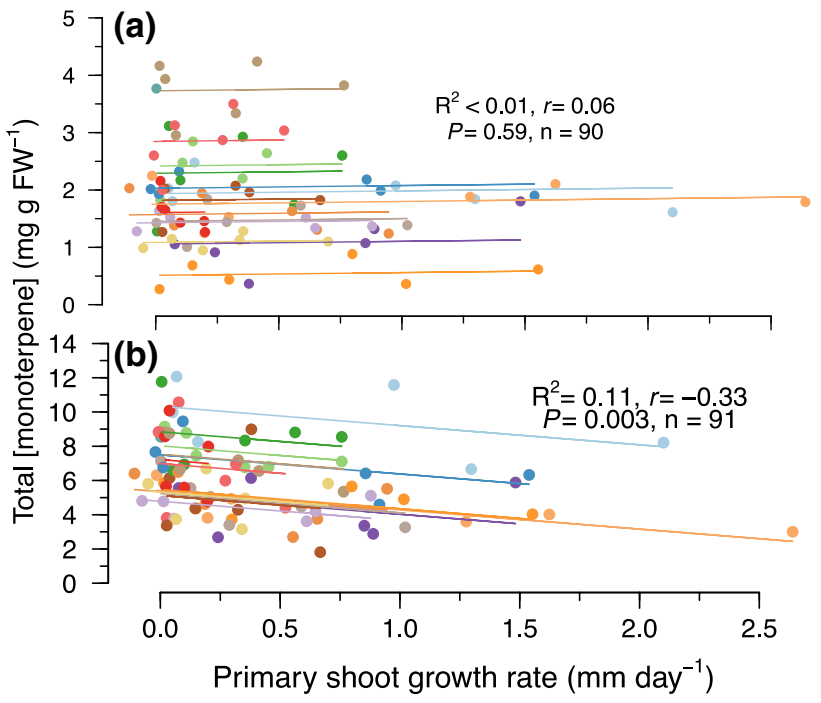

Fig. 4 Repeated measures correlations between total monoterpene concentrations $\left(\mathrm{mg} \mathrm{g} \mathrm{FW}^{-1}\right)$ and primary shoot growth rates $(\mathrm{mm}$ day $^{-1}$ ) in a needles and $\mathbf{b}$ woody tissue in Pinus edulis from the four treatments for six sampling periods from 2013 to 2014. Solid lines represent the best-fit repeated measures regression line for the data and the linear equations, $P$ values, repeated measures correlation coefficients $(r)$, and sample sizes $(n)$ are presented

common monoterpenes and made up $~ 84 \%$ of the total monoterpene composition in the needle tissue (Supporting Information Table S1) while (+)-a-pinene, $\delta$-3-carene, and $\beta$-myrcene made up $\sim 87 \%$ of the total monoterpene composition in the woody tissue (Supporting Information Table S2). Both treatment and time shifted the overall composition of monoterpenes in the needles (Supporting Information Table S3), but only the chemical profile of heat trees was different than ambient (Fig. 6a and Supporting Information Fig. S4a). Treatment and time also had significant effects on the overall composition of woody tissue monoterpenes (Supporting Information Table S3), but in contrast with needles, all treatment trees (heat, drought, and combined stress) demonstrated more distinctive monoterpene profiles relative to ambient (Fig. $6 \mathrm{~b}$ and Supporting Information Fig. S4b).

The treatments had significant effects on six of the fourteen compounds identified in the needles (Table 3). The most notable change in individual compound concentration involved an approximately twofold increase in (-)-a-pinene and (+)-a-pinene under combined heat and drought stress compared to heat alone (Fig. 7a and b). Similarly, R-(+)limonene increased threefold in response to drought and combined heat and drought (Fig. 7f); however, several other compounds (including its enantiomer) were notably unaffected by the treatments (e.g., $\beta$-myrcene, $\delta$-3-carene, and $S$-(-)-limonene concentrations, Fig. 7c, d, and e, respectively). NSC content never explained more than $12 \%$ of the 

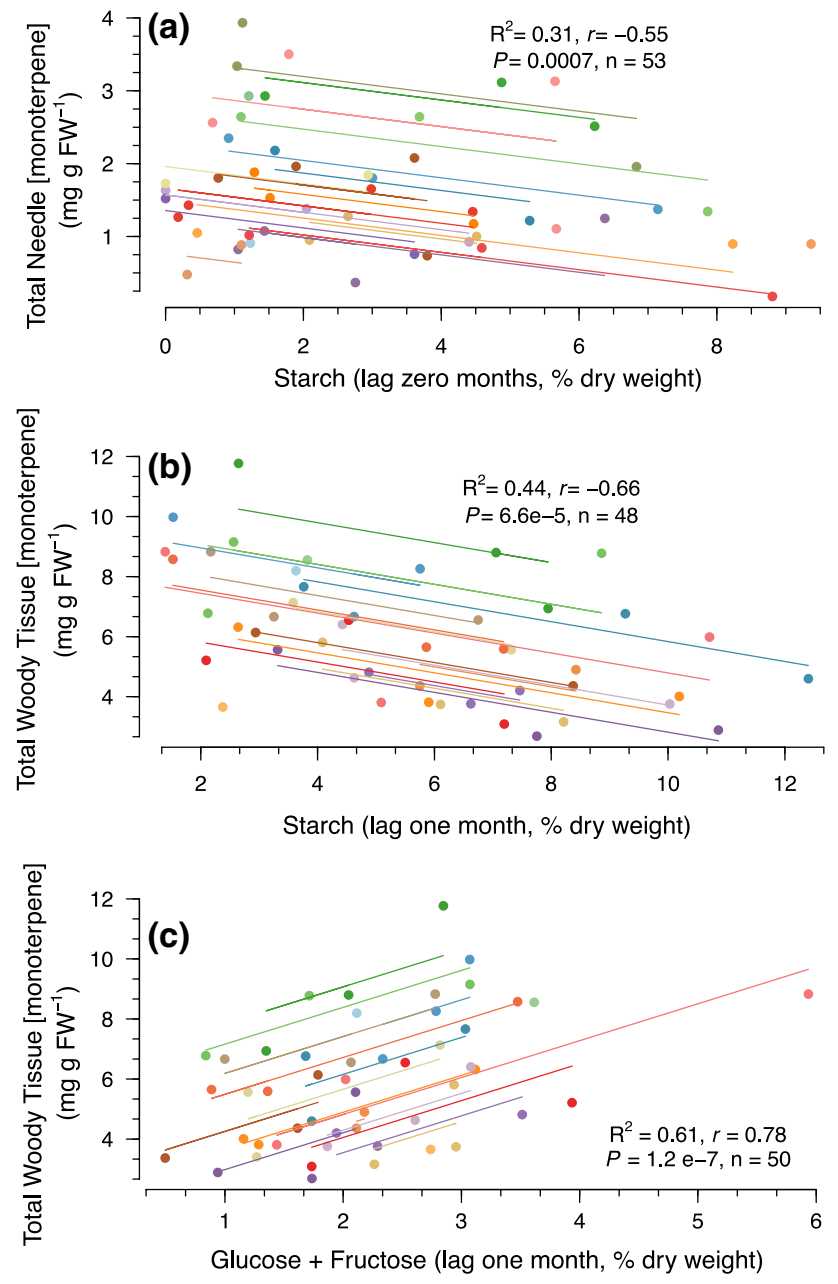

Fig. 5 The relationships between a needle total monoterpene concentrations ( $\mathrm{mg} \mathrm{g} \mathrm{FW}^{-1}$ ) and starch content (\% dry weight) measured during the same month, and between woody tissue total monoterpene concentration and $\mathbf{b}$ starch and $\mathbf{c}$ glucose + fructose on a 1-month time lag. Solid lines represent the best-fit repeated measures regression line for the data and the linear equations, $P$-values, repeated measures correlation coefficients $(r)$, and sample sizes $(n)$ are presented variation in individual compound concentrations in response to stress, except $\gamma$-terpinene in twigs where glucose + fructose explained $18 \%$ of the variance (Supporting Information Table S4).

Treatments had significant effects on nine of the fifteen compounds identified in the woody tissues (Table 3). Notable changes in individual compound concentrations included $\sim 62 \%$ and $42 \%$ increases in (-)-a-pinene (Fig. 8a) and (+)-a-pinene (Fig. 8b), respectively, in trees from the combined heat and drought treatment relative to ambient. Combined heat and drought trees also exhibited $\sim 60 \%$ increase in bornyl acetate (Table 3 ) and $~ 80 \%$ increases in (+)-R-limonene (Fig. 8f) and both enantiomers of camphene (Table 3). Like the pattern observed in needles, there was no treatment effect on $\beta$-myrcene concentrations (Fig. 8c). However, unlike the needles, heat significantly decreased levels of a number of woody tissue compounds relative to ambient including $S$-(-)-limonene (Fig. 8e), $\gamma$-terpinene, and terpinolene (Table 3 ). Heat alone also led to a threefold decrease in $\delta$-3-carene, and interestingly, drought and combined heat and drought caused a tenfold decrease relative to ambient (Fig. 8d). Several individual monoterpene compounds in the woody tissues were significantly correlated with glucose + fructose but not with starch or sucrose (Table 4). Similar to needle tissues, NSC content never explained more than $14 \%$ of the variation in individual compound concentrations in response to stress (Table 4).

\section{Discussion}

We leveraged a unique manipulative temperature and drought experiment to explore relationships between primary and secondary metabolism in mature piñon pine across a water-stress gradient in situ. The data support our hypothesis that, as predicted by the GDBH, monoterpene concentrations would increase in both tissues under drought stress (Fig. 2); however, increased stress/resource limitation by combined heat and drought only resulted in
Table 2 Correlations between leaf and twig total monoterpene concentrations and nonstructural carbohydrates in Pinus edulis

\begin{tabular}{llcclcr}
\hline Tissue & Lag & Total NSCs & Starch & Sucrose & Glucose + fructose & \multicolumn{1}{l}{ Total sugars } \\
\hline Leaf & 0 & $\mathbf{- 0 . 5 5 ( \mathbf { 0 . 0 0 0 7 } )}$ & $\mathbf{- 0 . 5 5 ( \mathbf { 0 . 0 0 0 7 } )}$ & $-0.29(0.09)$ & $-0.07(0.70)$ & $-0.48(0.004)$ \\
Leaf & 1 & $0.06(0.75)$ & $0.08(0.65)$ & $-0.23(0.23)$ & $0.14(0.45)$ & $-0.03(0.87)$ \\
Leaf & 2 & $0.38(0.16)$ & $0.51(0.051)$ & $-0.19(0.50)$ & $-0.14(0.61)$ & $-0.25(0.37)$ \\
Twig & 0 & $-0.10(0.56)$ & $-0.4(0.43)$ & $-0.21(0.23)$ & $0.33(0.04)$ & $0.05(0.76)$ \\
Twig & 1 & $-0.48(0.007)$ & $\mathbf{- 0 . 6 6 ( 6 \times \mathbf { 1 0 } ^ { - 5 } )}$ & $-0.02(0.93)$ & $\mathbf{0 . 7 8}\left(\mathbf{1} \times \mathbf{1 0}^{-7}\right)$ & $\mathbf{0 . 5 4}(\mathbf{0 . 0 0 2})$ \\
Twig & 2 & $0.014(0.96)$ & $0.06(0.84)$ & $-0.39(0.19)$ & $0.18(0.55)$ & $-0.09(0.77)$ \\
\hline
\end{tabular}

Repeated measures $r$ correlation coefficient $(P$ value) is displayed and significant correlations after applying the Bonferroni correction for multiple comparisons $(a<0.0017)$ are indicated in bold. Negative correlation coefficients represent increasing values of NSCs with increasing drought stress (more negative pre-dawn water potential values) while positive coefficients represent decreasing values of NSCs with increased drought stress 

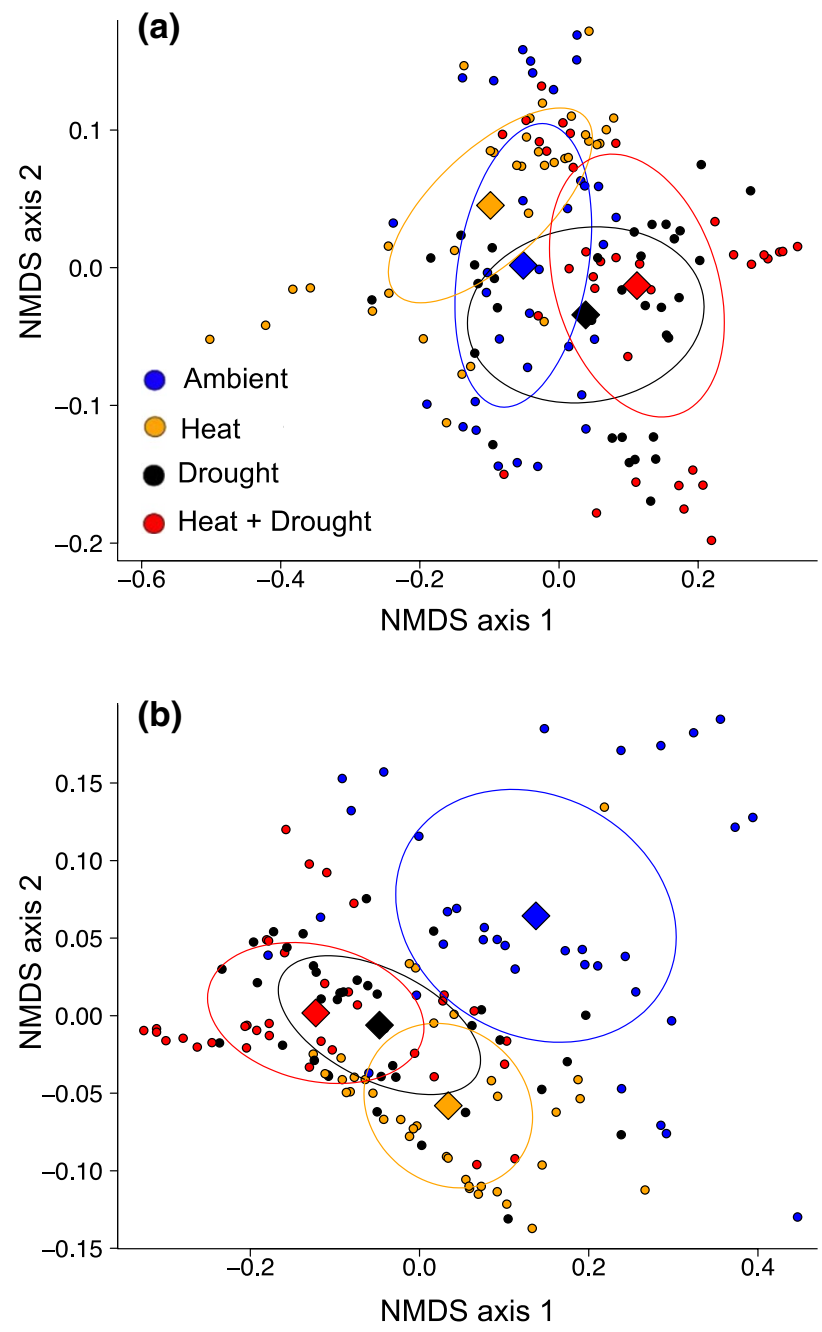

Fig. 6 Nonmetric multidimensional scaling (NMDS) of treatment effect on monoterpene composition in Pinus edulis a needles and $\mathbf{b}$ woody tissue across the four treatments averaged over nine sampling periods (2012-2016). Ellipses encircle the centroids (diamonds) and the relative monoterpene composition of all the tree individuals from the same treatment

greater monoterpene concentrations (relative to drought alone) in the woody tissues (Fig. 2b). Not only were woody tissue total monoterpene concentrations in trees under combined heat and drought significantly higher than levels observed in both heat-stressed and ambient trees, but this increase was sustained over multiple growing seasons (Fig. 3b). We also expected a relationship between monoterpenes and the soluble sugars sucrose, glucose, and fructose under increased stress due to a greater reliance on NSC mobilization to support monoterpene biosynthesis as photosynthesis declines. Maximum photosynthetic rates were suppressed under combined heat and drought stress, yet woody tissue monoterpene concentrations were elevated. Our data suggest these elevated woody tissue monoterpene levels in the face of low $A_{\max }$ rates are supported in part through fructose and glucose mobilization via starch hydrolysis (Fig. 5) on a 1-month lag. Furthermore, individual monoterpenes were affected by heat and drought in different ways (Table 3 ) highlighting the need to consider both tissue source and specific compounds as well as lags in effects when determining context for how and when monoterpene synthesis is regulated and the consequences for species interactions.

\section{Physiological variables and total monoterpenes}

Consistent with the GDBH and previous work in conifers (e.g., Llusia and Penuelas 1998; Turtola et al. 2003; Blanch et al. 2009), total monoterpene concentrations in both tissues increased under resource-limiting conditions (Fig. 2). These elevated levels under prolonged drought stress suggests that physiological stress levels required to initiate a decline in total monoterpene production in piñon pine likely occur at lower water potentials than observed, i.e. $<-3 \mathrm{MPa}$, which was not reached during our study due to access to deep soil water and amelioration of the imposed water limitation (Grossiord et al. 2017b; McDowell et al. 2019). While growth rates were correlated to woody tissue total monoterpenes, they did not explain more than $11 \%$ of variation in concentrations (Fig. 4b) offering very little mechanistic explanatory power. Rather, elevated total monoterpene concentrations in the combined heat and drought treatmentswith lower assimilation rates and reduced growth sink strength (Supporting Information Fig. S2) - suggest active defense response(s) to drought that are not controlled solely by source-driven processes or increased temperature. This is consistent with studies that have shown genes involved in biotic stress defenses to be upregulated in response to drought stress with concurrent downregulation of genes involved in cell division and growth (Dubos and Plomion 2003; Behringer et al. 2015; Moran et al. 2017). The severity and duration of stress required to exceed the physiological threshold(s) and initiating such responses remains relatively unknown for many species. Yet our data suggest that some stress level was reached and initiated a shift in the demand for monoterpenes. In fact, another study at our site showed that for two months prior to our first monoterpene sampling date, both $g_{\mathrm{s}}$ and net assimilation rates in the combined heat and drought stressed trees were significantly lower than ambient (Garcia-Forner et al. 2016). This is similar to patterns observed in Pinus sylvestris where monoterpenes only increased following periods of reduced $A_{\max }$ and $g_{\mathrm{s}}$ (SanchoKnapik et al. 2017). Thus, while monoterpene synthesis may be decoupled from instantaneous $A_{\max }$, relatively short and intense periods of reduced net assimilation rates can lead to a reprioritization of carbon from NSCs towards biosynthetic 
Table 3 Mean individual monoterpene concentrations from Pinus edulis needles and twigs

\begin{tabular}{|c|c|c|c|c|c|c|c|c|}
\hline \multirow[t]{2}{*}{ Compound } & \multicolumn{4}{|l|}{ Needles } & \multicolumn{4}{|l|}{ Woody tissue } \\
\hline & Ambient & Heat & Drought & Heat + drought & Ambient & Heat & Drought & Heat + drought \\
\hline (-)-a-Pinene & $285 \pm 49^{\mathrm{ab}}$ & $197 \pm 46^{\mathrm{a}}$ & $398 \pm 49^{\mathrm{b}}$ & $393 \pm 54^{\mathrm{b}}$ & $278 \pm 41^{\mathrm{a}}$ & $287 \pm 39^{a}$ & $414 \pm 40^{\mathrm{b}}$ & $451 \pm 44^{\mathrm{b}}$ \\
\hline (+)-a-Pinene & $324 \pm 118^{\mathrm{ab}}$ & $274 \pm 110^{\mathrm{a}}$ & $640 \pm 118^{\mathrm{bc}}$ & $830 \pm 130^{c}$ & $3547 \pm 0.518^{\mathrm{a}}$ & $3748 \pm 489^{\mathrm{a}}$ & $5050 \pm 511^{\mathrm{ab}}$ & $6334 \pm 561^{\mathrm{b}}$ \\
\hline Tricyclene & $3.4 \pm 1.3^{\mathrm{a}}$ & $4.2 \pm 1.2^{\mathrm{a}}$ & $5.0 \pm 1.3^{\mathrm{a}}$ & $6.2 \pm 1.5^{\mathrm{a}}$ & NA & NA & NA & NA \\
\hline (-)-Camphene & $0.7 \pm 0.2^{\mathrm{a}}$ & $0.6 \pm 0.2^{\mathrm{a}}$ & $0.6 \pm 0.2^{\mathrm{a}}$ & $0.6 \pm 0.2^{\mathrm{a}}$ & $12 \pm 1.5^{\mathrm{a}}$ & $13 \pm 1.5^{\mathrm{a}}$ & $17 \pm 1.5^{\mathrm{ab}}$ & $22 \pm 1.6^{\mathrm{b}}$ \\
\hline (+)-Camphene & $0.09 \pm 0.02^{\mathrm{ab}}$ & $0.07 \pm 0.02^{\mathrm{a}}$ & $0.12 \pm 0.02^{b c}$ & $0.14 \pm 0.02 \mathrm{~cd}$ & $23 \pm 3.5^{\mathrm{a}}$ & $24 \pm 3.3^{\mathrm{a}}$ & $33 \pm 3.5^{\mathrm{ab}}$ & $41 \pm 3.8^{\mathrm{b}}$ \\
\hline$\beta$-Myrcene & $75 \pm 17^{\mathrm{a}}$ & $79 \pm 16^{\mathrm{a}}$ & $95 \pm 17^{\mathrm{a}}$ & $112 \pm 19^{\mathrm{a}}$ & $592 \pm 128^{\mathrm{a}}$ & $272 \pm 120^{\mathrm{a}}$ & $521 \pm 126^{\mathrm{a}}$ & $524 \pm 139^{a}$ \\
\hline$(+)$ - $\beta$-Pinene & NA & NA & NA & NA & $27 \pm 4.9^{\mathrm{a}}$ & $23 \pm 4.6^{\mathrm{a}}$ & $31 \pm 4.8^{\mathrm{a}}$ & $36 \pm 5.3^{\mathrm{a}}$ \\
\hline$(-)$ - $\beta$-Pinene & $222 \pm 57^{\text {ac }}$ & $122 \pm 53^{\mathrm{a}}$ & $407 \pm 57^{\mathrm{b}}$ & $304 \pm 63^{b c}$ & $105 \pm 44^{\mathrm{a}}$ & $69 \pm 41^{\mathrm{a}}$ & $164 \pm 44^{\mathrm{a}}$ & $141 \pm 49^{\mathrm{a}}$ \\
\hline$\delta$-3-Carene & $8.8 \pm 1.8^{\mathrm{a}}$ & $6.3 \pm 1.7^{\mathrm{a}}$ & $6.8 \pm 1.8^{\mathrm{a}}$ & $8.5 \pm 2.0^{\mathrm{a}}$ & $835 \pm 162^{\mathrm{a}}$ & $258 \pm 150^{\mathrm{b}}$ & $95 \pm 162^{b}$ & $91 \pm 180^{\mathrm{b}}$ \\
\hline S-(-)-Limonene & $10 \pm 3^{\mathrm{a}}$ & $12 \pm 3^{\mathrm{a}}$ & $14 \pm 3^{\mathrm{a}}$ & $17 \pm 3^{\mathrm{a}}$ & $10 \pm 0.6^{\mathrm{a}}$ & $6.7 \pm 0.6^{\mathrm{b}}$ & $9 \pm 0.6^{\mathrm{a}}$ & $11 \pm 0.6^{\mathrm{a}}$ \\
\hline $\mathrm{R}-(+)$-Limonene & $5.8 \pm 1.6^{\mathrm{a}}$ & $4.7 \pm 1.5^{\mathrm{a}}$ & $10.8 \pm 1.6^{\mathrm{b}}$ & $10.9 \pm 1.7^{\mathrm{b}}$ & $18 \pm 2.5^{\mathrm{a}}$ & $18 \pm 2.4^{\mathrm{a}}$ & $25 \pm 2.5^{\mathrm{ab}}$ & $32 \pm 2.7^{b}$ \\
\hline$\beta$-Ocimene & NA & NA & NA & NA & $36 \pm 8.0^{\mathrm{a}}$ & $48 \pm 7.5^{\mathrm{a}}$ & $42 \pm 7.9^{\mathrm{a}}$ & $43 \pm 8.8^{\mathrm{a}}$ \\
\hline$\beta$-Phellandrene & $312 \pm 154^{\mathrm{a}}$ & $389 \pm 142^{\mathrm{a}}$ & $513 \pm 154^{\mathrm{a}}$ & $625 \pm 171^{\mathrm{a}}$ & $49 \pm 14^{\mathrm{a}}$ & $28 \pm 13^{\mathrm{a}}$ & $51 \pm 14^{\mathrm{a}}$ & $45 \pm 15^{\mathrm{a}}$ \\
\hline$\gamma$-Terpinene & $1.2 \pm 0.5^{\mathrm{a}}$ & $1.5 \pm 0.4^{\mathrm{a}}$ & $1.4 \pm 0.5^{\mathrm{a}}$ & $2.2 \pm 0.5^{\mathrm{a}}$ & $11 \pm 2.1^{\mathrm{a}}$ & $2 \pm 2.1^{\mathrm{b}}$ & $5 \pm 2.2^{\mathrm{ab}}$ & $5 \pm 2.4^{\mathrm{ab}}$ \\
\hline Terpinolene & $3.6 \pm 0.6^{\mathrm{a}}$ & $3.0 \pm 0.6^{\mathrm{a}}$ & $4.5 \pm 0.6^{\mathrm{ab}}$ & $5.7 \pm 0.6^{\mathrm{b}}$ & $95 \pm 13^{\mathrm{a}}$ & $28 \pm 12^{\mathrm{b}}$ & $39 \pm 12^{b}$ & $32 \pm 14^{\mathrm{b}}$ \\
\hline Bornyl acetate & $117 \pm 39^{\mathrm{a}}$ & $86 \pm 36^{\mathrm{a}}$ & $105 \pm 39^{\mathrm{a}}$ & $74 \pm 24^{\mathrm{a}}$ & $47 \pm 6.6^{\mathrm{ac}}$ & $43 \pm 6.2^{\mathrm{a}}$ & $64 \pm 6.5^{b}$ & $75 \pm 7.1^{b c}$ \\
\hline
\end{tabular}

Differences in lower case letters represent significant differences in concentrations between treatments for each compound and tissue type are designated by $(\alpha<0.05)$

pathways associated with chemical defense that is sustained for extended periods.

\section{Non-structural carbohydrates and total monoterpenes}

With a significant decrease in photosynthetic rate, conifers rely on NSCs as a carbon source (Hartmann et al. 2013; Sevanto et al. 2014) and can synthesize carbon-based monoterpenes at the cost of storage and other secondary metabolites (Huang et al. 2019a). As hypothesized, increases in total monoterpene concentrations in woody tissues under water-limiting conditions were correlated with NSCs, namely fructose and glucose likely mobilized via starch hydrolysis (Fig. 5b and c). These observations indicate a link between chemical defenses and whole-tree carbon and water economics due to the spatiotemporal variation that exists in NSC storage and transport. These links, however, appear to be tissue specific and manifest themselves over different environmental conditions and time scales.

Specific plant tissues are known to possess different NSC allocation strategies that not only help cope with drought but can have important consequences for chemical defenses. Total monoterpenes in needles were not significantly correlated with total sugars, which explained some $23 \%$ of the variation in monoterpene concentrations (Table 2). This relatively poor relationship is likely due to the multifunctionality of sugars in leaf tissues where high quantities of soluble sugars are required to maintain normal cellular turgor (DeSchepper and Steppe 2011) while simultaneously supporting respiration and other critical processes. This weak correlation also suggests that other unmeasured carbon sources are supporting elevated monoterpene levels in the leaves under drought conditions (Fig. 2a). In contrast to leaf tissues in our study, total monoterpenes in the woody tissues were related to the previous month's starch and glucose + fructose content (Fig. 5b and c), which explained more than $40 \%$ and $60 \%$ of the variation, respectively. These data suggest that drought-induced monoterpene synthesis in woody tissues is in part supported by starch hydrolysis as a source of soluble sugar substrates among other intermediate and stored carbon sources, the dynamics of which have yet to be identified. The delayed availability of glucose from starch (via starch synthesis, followed by hydrolysis and subsequent sugar transport to sites of monoterpene synthesis) may also explain the lag observed for concentration changes in these tissues (Table 2 and Fig. 3b).

While the NSCs measured did not explain more than $18 \%$ of the variation in drought-induced changes in individual monoterpene concentrations (Table 4 and Supporting Information Table S4), this does not preclude that other NSCs contribute to their synthesis. In addition, trade-offs between defenses and carbohydrate reserves may only manifest under more profound carbon limitations (Zust and Agrawal 2017) that were not reached in the present field-based study (McDowell et al. 2019). Nonetheless, these tissue-, organ- and compound-specific relationships with NSCs suggest synthesis controls beyond passive carbon source-sink 

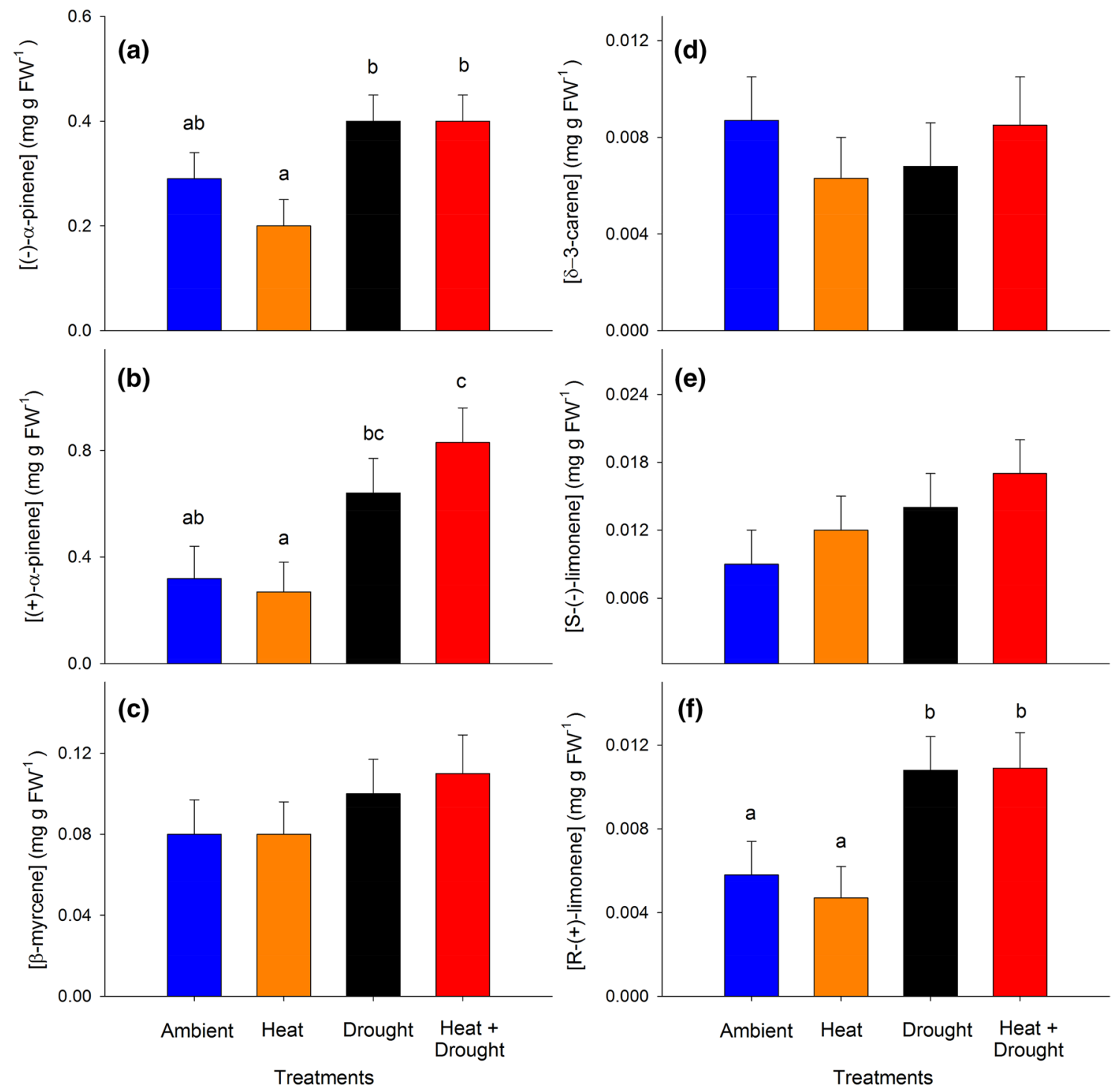

Fig. 7 Mean individual monoterpene concentrations ( $\mathrm{mg} \mathrm{g}^{-1} \mathrm{FW}$ ) of six compounds found in Pinus edulis current and one-year old needle tissue across the four treatments averaged over nine sampling periods (2012-2016). a (-)-a-Pinene, b (+)-a -pinene, $\mathbf{c} \beta$-myrcene, $\mathbf{d}$

ס-3-carene, e S-(-)-limonene, f) R-(+)-limonene. Compounds were chosen to highlight the variation in responses across treatments and tissues. Bars represent means \pm SEM and significance between treatments is expressed using different lowercase letters $(a<0.05)$

dynamics, likely involving drought-induced phytohormonal signaling and the active gene regulation of specific monoterpene synthases (Radwan et al. 2017).

\section{Compositional responses of monoterpenes to heat and drought stress}

Drought affects secondary compound synthesis via changes in source-sink carbon dynamics and also by altering the activities of key enzymes responsible for producing individual compounds like monoterpene synthases (Keeling and Bohlmann 2006). We observed compoundand tissue-specific changes in individual monoterpene

concentrations and overall composition in response to the treatments (Table 3, Fig. 6). Notably, the differences in monoterpene profiles between trees exposed to the treatments and controls were greater in the woody tissue than in needles (Fig. 6). While it is common for chemical composition to differ between organs (Sjödin et al. 1996, 2000), the ways in which drought, heat, and their combination affect chemical diversity is less understood. It is possible that drought and heat affect monoterpene composition more in woody tissues as opposed to young needles due to either constraint on carbon transport (Sevanto 2014) and/or different biosynthetic processes in the tissue types (Manninen et al. 2002). Carbon is not allocated 


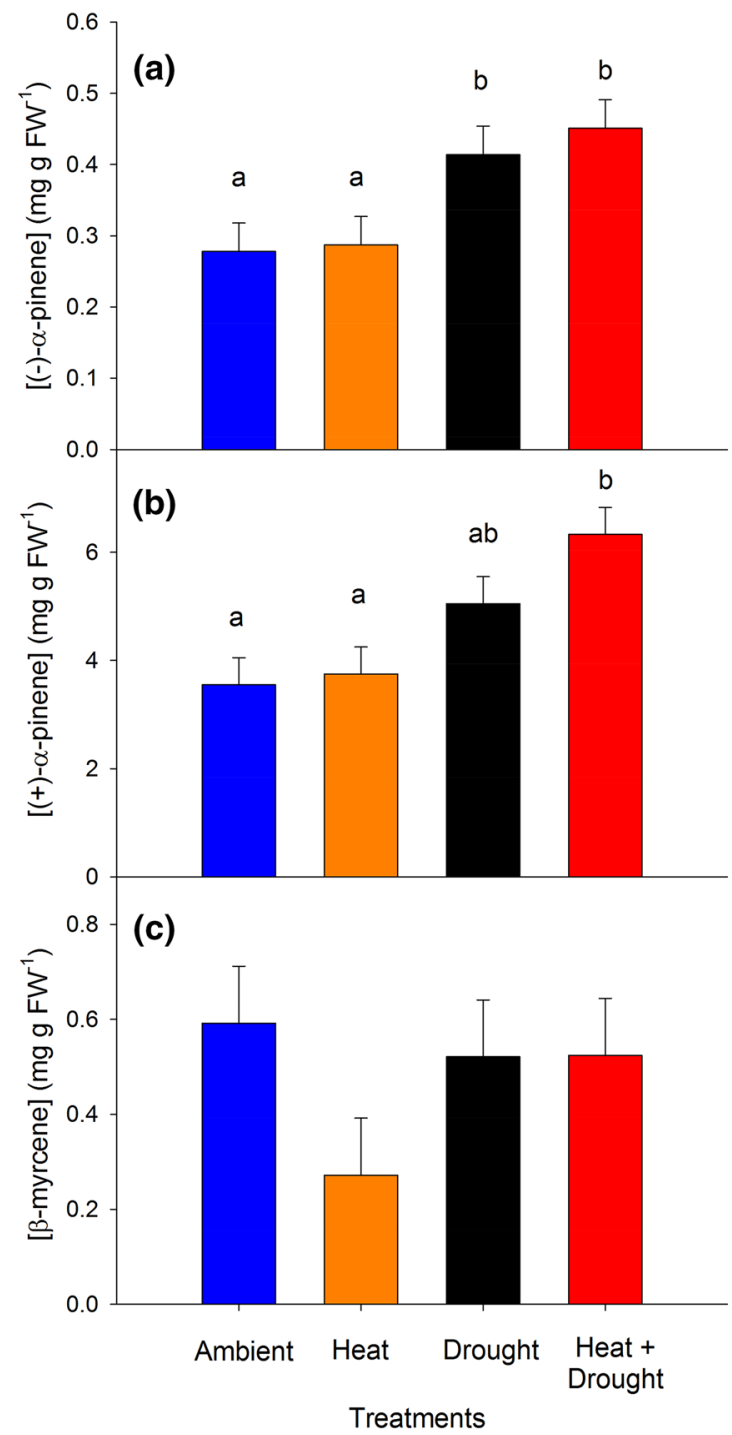

Fig. 8 Monoterpene concentrations ( $\mathrm{mg} \mathrm{g}^{-1} \mathrm{FW}$ ) of six compounds in Pinus edulis woody tissue across the four treatments averaged over nine sampling periods (2012-2016). a (-)-a-Pinene, b (+)-a -pinene, c $\beta$-myrcene, d $\delta$-3-carene, e S-(-)-limonene, f $\mathrm{R}$-(+)-

to individual compounds equally and is likely related to shifts in synthase enzyme activity that are differentially induced by heat and drought stress (Radwan et al. 2017). Because monoterpenes originate from the same precursor molecule, geranyl diphosphate, it is likely that these stressinduced shifts in individual concentrations are due to synthase activation, a topic that requires additional research. Identifying molecular mechanisms responsible for heatand drought-induced shifts in monoterpene diversity will require a combination of transcriptomics, metabolomics, and stable isotope approaches, and our findings provide key insights that can be used to develop testable hypotheses to explain these targeted allocation patterns.

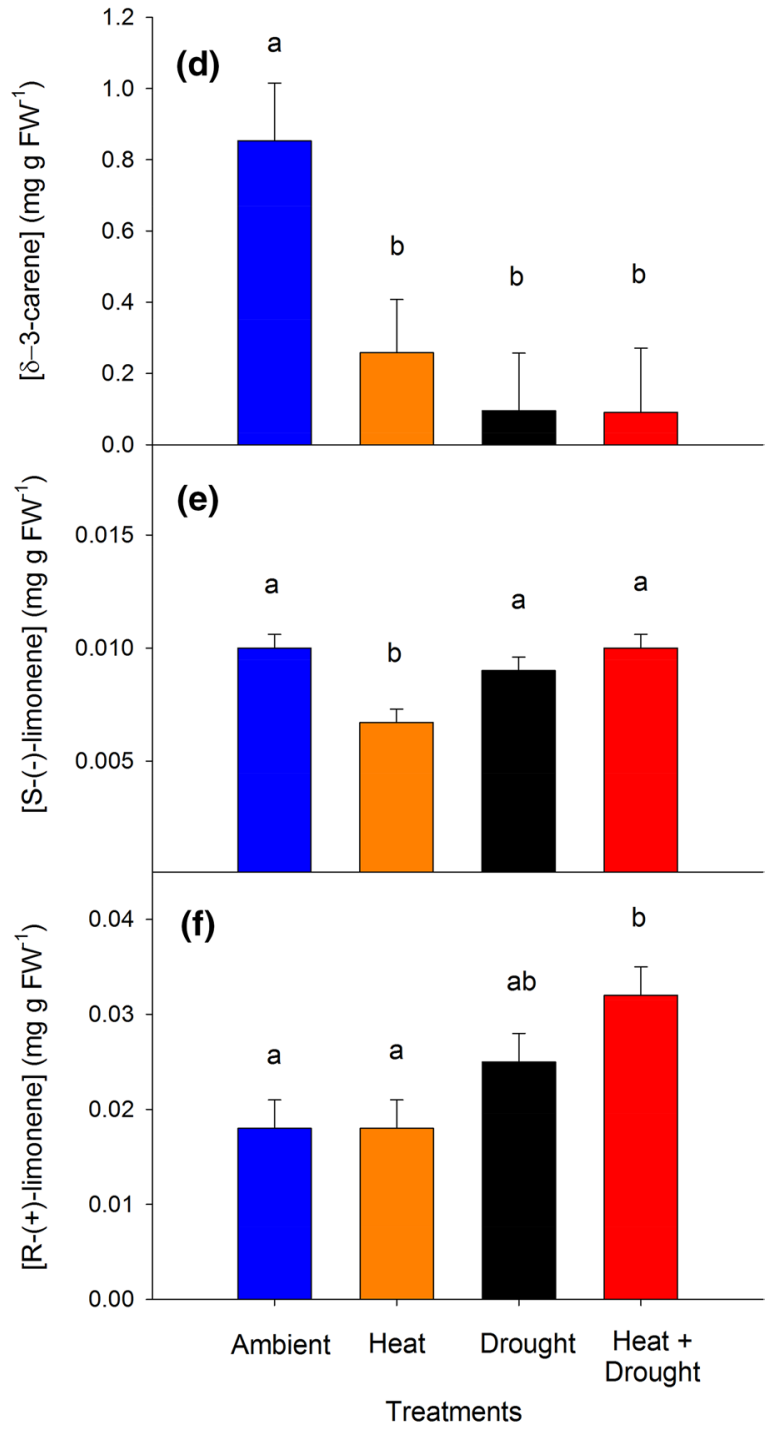

limonene. Compounds were chosen to highlight the variation in responses across treatments and tissues. Bars are means \pm SEM and significance between treatments is expressed using different lowercase letters $(a<0.05)$

It is widely accepted that conifers become more susceptible to biotic attacks during drought due to decreased levels of defense compounds (Mattson and Haack 1987; Dobbertin et al. 2007; McDowell et al. 2011; Gaylord et al. 2013; Netherer et al. 2015). We identified decreased concentrations of some compounds despite overall increases in major constituents of the monoterpene profile. Drought-induced shifts in individual compounds may result from cumulative past evolutionary pressures, including drought-induced bark beetle attacks, especially given the unique changes to monoterpene profiles in woody tissue (Fig. 6). For example, drought and combined heat and drought stress increased levels of woody tissue (-)-a-pinene (Fig. 8a), a precursor molecule used by I. confusus to produce cis-verbenol, a minor constituent 
Table 4 Correlations between individual monoterpene concentrations and non-structural carbohydrates in twigs of Pinus edulis

\begin{tabular}{|c|c|c|c|}
\hline Compound & Starch & Sucrose & Glucose + fructose \\
\hline (-)-a-Pinene & $-0.24(0.016)$ & $-0.09(0.39)$ & $0.38\left(9 \times 10^{-5}\right)$ \\
\hline$(+)$-a-Pinene & $-0.29(0.003)$ & $-0.04(0.69)$ & $0.31(0.001)$ \\
\hline (-)-Camphene & $-0.24(0.017)$ & $-0.06(0.53)$ & $0.29(0.002)$ \\
\hline (+)-Camphene & $-0.30(0.002)$ & $-0.06(0.54)$ & $0.33(0.0007)$ \\
\hline$\beta$-Myrcene & $-0.25(0.012)$ & $-0.002(0.98)$ & $0.25(0.009)$ \\
\hline$(+)-\beta$-Pinene & $-0.27(0.007)$ & $-0.10(0.32)$ & $0.26(0.008)$ \\
\hline$(-)$ - $\beta$-Pinene & $0.09(0.40)$ & $-0.07(0.48)$ & $-0.002(0.99)$ \\
\hline$\delta$-3-Carene & $-0.19(0.06)$ & $-0.06(0.51)$ & $0.29(0.003)$ \\
\hline (-)-Limonene & $-0.23(0.02)$ & $-0.11(0.27)$ & $0.29(0.003)$ \\
\hline (+)-Limonene & $-0.26(0.01)$ & $-0.04(0.67)$ & $0.36(0.0002)$ \\
\hline$\beta$-Ocimene & $-0.17(0.08)$ & $-0.08(0.42)$ & $0.18(0.06)$ \\
\hline$\beta$-Phellandrene & $-0.07(0.49)$ & $-0.02(0.81)$ & $0.05(0.61)$ \\
\hline g-Terpinene & $-0.008(0.93)$ & $0.07(0.48)$ & $0.04(0.71)$ \\
\hline Terpinolene & $-0.23(0.02)$ & $-0.01(0.92)$ & $0.28(0.004)$ \\
\hline Bornyl acetate & $-0.21(0.03)$ & $0.01(0.90)$ & $0.29(0.003)$ \\
\hline
\end{tabular}

Repeated measures $r$ correlation coefficient ( $P$ value) is displayed and significant correlations after applying the Bonferroni correction for multiple comparisons $(a<0.0011)$ are indicated in bold. Negative correlation coefficients represent increasing values of NSCs with increasing drought stress (more negative pre-dawn water potential values) while positive coefficients represent decreasing values of NSCs with increased drought stress

of the bark beetle's pheromone blend that also consists of monoterpenoid alcohols (ipsenol and ipsdienol) synthesized de novo from the beetles themselves (Tittiger and Blomquist 2016; Fisher et al. 2021). In addition, our combined heat and drought treatments decreased levels of other woody tissue compounds, most notably (-)- $\delta$-3-carene (Fig. 8d). High levels of $\delta$-3-carene are characteristic of more resistant trees (Boone et al. 2011; Erbilgin et al. 2017) due to toxicity to bark beetles (Raffa and Berryman 1987; Raffa et al. 2005) and negative effects on the growth of symbiotic fungi (Raffa and Berryman 1983). While the effects of $\delta$-3-carene on $I$. confusus are yet to be determined, the impact of this particular compound on both aggressive and non-aggressive bark beetle-fungi complexes suggests that its toxicity may be relatively common among taxa. Given the benefit of $(-)$-a-pinene as an aggregation pheromone precursor for $I$. confusus and the general toxicity of $\delta$-3-carene to the bark beetle-fungal complex, higher (-)-a-pinene and lower $\delta-3$ carene levels under combined heat and drought conditions may make these trees more favorable for bark beetle attack, rather than well-defended, which one might conclude if only studying monoterpene concentrations in total. Whether these shifts are enough to promote attack by Ips confusus (piñon engraver beetle) requires field studies investigating these mechanisms under more severe drought stress as well as bioassays that can provide a clearer understanding of how these altered profiles impact bark beetle choice and success.

\section{Conclusions}

Two of the more important abiotic stressors affecting tree function are heat and drought, yet adequate tests of defense responses in mature trees to these stressors are rare and often fail to consider their interactive effects. Our experimental design allowed us to observe heat and drought-induced changes in monoterpenes in relation to growth, $\mathrm{C}$ assimilation, and NSCs over a range of water potentials that provided an opportunity to evaluate mechanistic underpinnings in the context of theory (GDBH) and potential impacts on destructive biotic agents. Our results point towards droughtinduced changes in monoterpenes where cumulative climatic effects activate a reprioritization of source and sink strengths and thus allocation towards defense. While some aspects of our findings are consistent with the predictions of the GDBH, our results challenge source-based processes and suggest sophisticated signaling mechanisms are at play that actively reallocate NSCs to specific defense compounds after critical physiological thresholds induced by drought are surpassed. We found the interactive effects of heat and drought on monoterpenes to be frequently synergistic and sustained, although some compounds were insensitive or decreased in response to either stress across the levels we observed. This is critical to note as particular compounds play important roles in defense against biotic attacks. As such, it is imperative that the dynamics identified here continue to be studied to identify when key defensive compounds decline as drought becomes more severe, and how this occurs through NSC availability via gene regulation. It is clear that drought and heat stress change plant metabolism at levels ranging from enzymes to whole organisms. Coupling advanced metabolomics techniques to field-based experimental research may further illuminate the changes that plants undergo to defend against pest and pathogen attack while under physiological stress.

Supplementary Information The online version contains supplementary material available at https://doi.org/10.1007/s00442-021-05058-8.

Acknowledgements This manuscript is to be published as part of a Special Issue honoring Russ Monson. We appreciate Russ's contributions towards elucidating environmental controls over monoterpene synthesis and empirical testing of plant resource allocation theories. We gratefully acknowledge Veronica Lourich for assistance with data organization, and numerous undergraduate students who helped process samples. We also thank Isaac Borrego, Samuel Briggs, William Hammond, Núria Garcia-Forner, Alissa Freeman, Michael Jenkins, Heath Powers, Liz Stockton, and others who worked at SUMO for assistance with data and sample collection. 
Author contribution statement AMT, HDA, and NGM planned and designed the research. AC, LTD, CG, SS, HAD, and NGM conducted the field work and processed the primary physiology data. AMT, MH, and DKM processed samples for monoterpene chemistry. SM conducted multivariate statistical analyses and PCS performed correlations and analyzed data for lag effects. AMT wrote the manuscript with input from all co-authors.

Funding This research was supported by an award to AMT and HDA from the National Science Foundation (NSF), Division of Integrative Organismal Systems, Integrative Ecological Physiology Program (IOS-1755346 and IOS-1755345). AMT was also supported by U.S. Department of Energy Office of Science (BER) (DE-SC0010845) and by an NSF Postdoctoral Research Fellowship in Biology (1309051). HDA was supported by the USDA National Institute of Food and Agriculture, McIntire Stennis project WNP00009. The SUMO experiment was supported by the US Department of Energy, Office of Science, Biological and Environmental Research, and Los Alamos National Laboratory Directed Research, including the postdoctoral program.

Availability of data and material The data that support the findings of this study are openly available in Figshare.

Code availability Not applicable.

\section{Declarations}

Conflict of interest The authors declare that they have no conflict of interest.

Ethics approval Not applicable.

Consent to participate Not applicable.

Consent for publication Not applicable.

Open Access This article is licensed under a Creative Commons Attribution 4.0 International License, which permits use, sharing, adaptation, distribution and reproduction in any medium or format, as long as you give appropriate credit to the original author(s) and the source, provide a link to the Creative Commons licence, and indicate if changes were made. The images or other third party material in this article are included in the article's Creative Commons licence, unless indicated otherwise in a credit line to the material. If material is not included in the article's Creative Commons licence and your intended use is not permitted by statutory regulation or exceeds the permitted use, you will need to obtain permission directly from the copyright holder. To view a copy of this licence, visit http://creativecommons.org/licenses/by/4.0/.

\section{References}

Adams HD, Collins AD, Briggs SP, Vennetier M, Dickman LT, Sevanto SA, Garcia-Forner N, Powers HH, McDowell NG (2015) Experimental drought and heat can delay phenological development and reduce foliar and shoot growth in semiarid trees. Glob Change Biol 21:4210-4220. https://doi.org/10.1111/gcb.13030

Adams HD, Zeppel MJB, Anderegg WRL, Hartmann H, Landhäusser SM, Tissue DT, Huxman TE, Hudson PJ, Franz TE, Allen CD (2017) A multi-species synthesis of physiological mechanisms in drought-induced tree mortality. Nat Ecol Evol 1:1285-1291. https://doi.org/10.1038/s41559-017-0248-x

Allen CD, Macalady AK, Chenchouni H, Bachelet D, McDowell N, Vennetier M, Kitzberger T, Rigling A, Breshears DD, Hogg EH, Gonzalez P, Fensham R, Zhang Z, Castro J, Demidova N, Lim J-H, Allard G, Running SW, Semerci A, Cobb N (2010) A global overview of drought and heat-induced tree mortality reveals emerging climate change risks for forests. For Ecol Manag 259:660-684. https://doi.org/10.1016/j.foreco.2009.09.001

Allen CD, Breshears DD, McDowell NG (2015) On underestimation of global vulnerability to tree mortality and forest die-off from hotter drought in the Anthropocene. Ecosphere 6:1-55. https://doi.org/ 10.1890/ES15-00203.1

Anderegg WRL, Berry JA, Smith DD, Sperry JS, Anderegg LDL, Field CB (2012) The roles of hydraulic and carbon stress in a widespread climate-induced forest die-off. Proc Natl Acad Sci USA 109:233-237. https://doi.org/10.1073/pnas.1107891109

Anderegg WRL, Hicke JA, Fisher RA, Allen CD, Aukema J, Bentz B, Hood S, Lichstein JW, Macalady AK, McDowell N, Pan Y, Raffa K, Sala A, Shaw JD, Stephenson NL, Tague C, Zeppel M (2015) Tree mortality from drought, insects, and their interactions in a changing climate. New Phytol 208:674-683. https://doi.org/10. 1111/nph.13477

Anderson MJ (2014) Permutational multivariate analysis of variance (PERMANOVA). Wiley StatsRef: statistics reference online. Wiley. https://doi.org/10.1002/9781118445112.stat07841

Bakdash JZ, Marusich LR (2017) Repeated measures correlation. Front Psychol 8:456. https://doi.org/10.3389/fpsyg.2017.00456

Behringer D, Zimmermann H, Ziegenhagen B, Liepelt S (2015) Differential gene expression reveals candidate genes for drought stress response in Abies alba (Pinaceae). PLoS ONE 10(4):e0124564. https://doi.org/10.1371/journal.pone.0124564

Bentz BJ, Régnière J, Fettig CJ, Hansen EM, Hayes JL, Hicke JA, Kelsey RG, Negrón JF, Seybold SJ (2010) Climate change and bark beetles of the western United States and Canada: direct and indirect effects. Bioscience 60:602-613. https://doi.org/10. 1525/bio.2010.60.8.6

Blanch JS, Penuelas J, Sardans J, Llusia J (2009) Drought, warming and soil fertilization effects on leaf volatile terpene concentrations in Pinus halepensis and Quercus ilex. Acta Physiol Plant 31:207. https://doi.org/10.1007/s11738-008-0221-z

Blomquist GJ, Figueroa-Teran R, Aw M, Song M, Gorzalski A, Abbott NL, Chang E, Tittiger C (2010) Pheromone production in bark beetles. Insect Biochem Mol 40:699-712. https://doi. org/10.1016/j.ibmb.2010.07.013

Boone CK, Aukema BH, Bohlmann J, Carroll AL, Raffa KF (2011) Efficacy of tree defense physiology varies with bark beetle population density: a basis for positive feedback in eruptive species. Can J Forest Res 41:1174-1188. https://doi.org/10. 1139/x11-041

Byers JA (2007) Chemical ecology of bark beetles in a complex olfactory landscape. In: Lieutier F, Day KR, Battisti A, Grégoire JC, Evans HF (eds) Bark and wood boring insects in living trees in Europe, a synthesis. Springer, Dordrecht, pp 89-132. https://doi. org/10.1007/978-1-4020-2241-8_8

Cheng AX, Lou YG, Mao YB, Lu S, Wang LJ, Chen XY (2007) Plant terpenoids: biosynthesis and ecological functions. J Integr Plant Biol 49:179-186. https://doi.org/10.1111/j.1744-7909.2007. 00395.x

Chiu CC, Keeling CI, Bohlmann J (2018) Monoterpenyl esters in juvenile mountain pine beetle and sex-specific release of the aggregation pheromone trans-verbenol. Proc Natl Acad Sci USA 115:3652-3657. https://doi.org/10.1073/pnas.1722380115

Christiansen E, Waring RH, Berryman AA (1987) Resistance of conifers to bark beetle attack: searching for general relationships. For 
Ecol Manag 22:89-106. https://doi.org/10.1016/0378-1127(87) 90098-3

De Schepper V, Steppe K (2011) Tree girdling responses simulated by a water and carbon transport model. Ann Bot 108:1147-1154. https://doi.org/10.1093/aob/mcr068

Dickman LT, McDowell NG, Sevanto S, Pangle RE, Pockman WT (2015) Carbohydrate dynamics and mortality in a pinon-juniper woodland under three future precipitation scenarios. Plant Cell Environ 38:729-739. https://doi.org/10.1111/pce.12441

Dobbertin M, Wermelinger B, Bigler C, Bürgi M, Carron M, Forster B, Gimmi U, Rigling A (2007) Linking increasing drought stress to Scots pine mortality and bark beetle infestations. Sci World J 7:369535. https://doi.org/10.1100/tsw.2007.58

Dubos C, Plomion C (2003) Identification of water-deficit responsive genes in maritime pine (Pinus pinaster Ait.) roots. Plant Mol Biol 51:249-262. https://doi.org/10.1023/A:1021168811590

Erbilgin N, Powell JS, Raffa KF (2003) Effect of varying monoterpene concentrations on the response of Ips pini (Coleoptera: Scolytidae) to its aggregation pheromone: implications for pest management and ecology of bark beetles. Agr for Entomol 5:269-274. https://doi.org/10.1046/j.1461-9563.2003.00186.x

Erbilgin N, Cale JA, Hussain A, Ishangulyyeva G, Klutsch JG, Najar A, Zhao S (2017) Weathering the storm: how lodgepole pine trees survive mountain pine beetle outbreaks. Oecologia 184:469-478. https://doi.org/10.1007/s00442-017-3865-9

Fisher KE, Tillett RL, Fotoohi M, Caldwell C, Petereit J, Schlauch K, Tittiger C, Blomquist GJ, MacLean M (2021) RNA-Seq used to identify ipsdienone reductase (IDONER): a novel monoterpene carbon-carbon double bond reductase central to Ips confusus pheromone production. Insect Biochem Mol 129:103513. https://doi. org/10.1016/j.ibmb.2020.103513

Franceschi VR, Krokene P, Christiansen E, Krekling T (2005) Anatomical and chemical defenses of conifer bark against bark beetles and other pests. New Phytol 167:353-375. https://doi.org/ 10.1111/j.1469-8137.2005.01436.x

Galiano L, Martinez-Vilalta J, Lloret F (2011) Carbon reserves and canopy defoliation determine the recovery of Scots pine 4 years after a drought episode. New Phytol 190:750-759. https://doi. org/10.1111/j.1469-8137.2010.03628.x

Garcia-Forner N, Adams HD, Sevanto S, Collins AD, Dickman LT, Hudson PJ, Zeppel MJ, Jenkins MW, Powers H, MartinezVilalta J, McDowell NG (2016) Responses of two semiarid conifer tree species to reduced precipitation and warming reveal new perspectives for stomatal regulation. Plant Cell Environ 39:38-49. https://doi.org/10.1111/pce.12588

Gaylord ML, Kolb TE, Pockman WT, Plaut JA, Yepez EA, Macalady AK, Pangle RE, McDowell NG (2013) Drought predisposes pinon-juniper woodlands to insect attacks and mortality. New Phytol 198:567-578. https://doi.org/10.1111/nph.12174

Grossiord C, Sevanto S, Adams HD, Collins AD, Dickman LT, McBranch N, Michaletz ST, Stockton EA, Vigil M, McDowell NG (2017a) Precipitation, not air temperature, drives functional responses of trees in semi-arid ecosystems. J Ecol 105:163-175. https://doi.org/10.1111/1365-2745.12662

Grossiord C, Sevanto S, Dawson TE, Adams HD, Collins AD, Dickman LT, Newman BD, Stockton EA, McDowell NG (2017b) Warming combined with more extreme precipitation regimes modifies the water sources used by trees. New Phytol 213:584596. https://doi.org/10.1111/nph.14192

Hartmann H, Trumbore S (2016) Understanding the roles of nonstructural carbohydrates in forest trees-from what we can measure to what we want to know. New Phytol 211:386-403. https:// doi.org/10.1111/nph.13955

Hartmann H, Ziegler W, Kolle O, Trumbore S (2013) Thirst beats hunger-declining hydration during drought prevents carbon starvation in Norway spruce saplings. New Phytol 200:340-349. https://doi.org/10.1111/nph.12331

Hartmann H, Moura CF, Anderegg WRL, Ruehr NK, Salmon Y, Allen CD, Arndt SK, Breshears DD, Davi H, Galbraith D, Ruthrof KX, Wunder J, Adams HD, Bloemen J, Cailleret M, Cobb R, Gessler A, Grams TEE, Jansen S, Kautz M, Lloret F, O'Brien M (2018) Research frontiers for improving our understanding of drought-induced tree and forest mortality. New Phytol 218:15-28. https://doi.org/10.1111/nph.15048

Herms DA, Mattson WJ (1992) The dilemma of plants: to grow or defend. Q Rev Biol 67:283-335. https://doi.org/10.1086/417659

Hoch G, Popp M, Körner C (2002) Altitudinal increase of mobile carbon pools in Pinus cembra suggests sink limitation of growth at the Swiss treeline. Oikos 98:361-374. https://doi.org/10. 1034/j.1600-0706.2002.980301.x

Huang J, Hammerbacher A, Weinhold A, Reichelt M, Gleixner G, Behrendt T, Van Dam NM, Sala A, Gershenzon J, Trumbore S, Hartman H (2019a) Eyes on the future-evidence for trade-offs between growth, storage and defense in Norway spruce. New Phytol 222:144-158. https://doi.org/10.1111/nph.15522

Huang J, Forkelova L, Unsicker SB, Forkel M, Griffith DW, Trumbore S, Harmann H (2019b) Isotope labeling reveals contribution of newly fixed carbon to carbon storage and monoterpene production under water deficit and carbon limitation. Environ Exp Bot 162:333-344. https://doi.org/10.1016/j.envexpbot. 2019.03.010

Huang J, Kautz M, Trowbridge AM, Hammerbacher A, Raffa KF, Adams HD, Goodsman DW, Xu C, Meddens AJ, Kandasamy D, Gershenzon J (2020) Tree defence and bark beetles in a drying world: carbon partitioning, functioning and modelling. New Phytol 225:26-36. https://doi.org/10.1111/nph.16173

IPCC (2014) Impacts, adaptation, and vulnerability part b: regional aspects. In: Barros VR, Field CB, Dokken DJ, Mastrandre MD (eds) Contribution of working group II to the Fifth assessment report of the intergovernmental panel on climate change. Cambridge University Press, Cambridge and New York

Keefover-Ring K, Trowbridge A, Mason C, Raffa K (2016) Rapid induction of multiple terpenoid groups by ponderosa pine in response to bark beetle-associated fungi. J Chem Ecol 42:1-12. https://doi.org/10.1007/s10886-015-0659-6

Keeling CI, Bohlmann J (2006) Genes, enzymes and chemicals of terpenoid diversity in the constitutive and induced defence of conifers against insects and pathogens. New Phytol 170:657-675. https://doi.org/10.1111/j.1469-8137.2006.01716.x

Klutsch JG, Shamoun SF, Erbilgin N (2017) Drought stress leads to systemic induced susceptibility to a nectrotrophic fungus associated with mountain pine beetle in Pinus banksiana seedlings. PLoS ONE 12:e0189203. https://doi.org/10.1371/journal.pone. 0189203

Landhausser SM, Chow PS, Dickman LT, Furze ME, Kuhlman I, Schmid S, Wiesenbauer J, Wild B, Gleixner G, Hartmann H, Hoch G (2018) Standarized protocols and procedures can precisely and accurately quantify non-structural carbohydrates. Tree Physiol 38:1764-1778. https://doi.org/10.1093/treephys/tpy 118

Li MH, Jiang Y, Wang A, Li X, Zhu W, Yan CF, Du Z, Shi Z, Lei SL, He P (2018) Active summer carbon storage for winter persistence in trees at the cold alpine treeline. Tree Physiol 38:1345-1355. https://doi.org/10.1093/treephys/tpy020

Llusia J, Penulas J (1998) Seasonal patterns of terpene content and emission from seven Mediterranean woody species in field conditions. Am J Bot 87:133-140. https://doi.org/10.2307/2656691

Loomis WE (1932) Growth-differentiation balance vs. carbohydratenitrogen ratio. Proc Am Soc Hortic Sci 29:240-245

Loreto F, Schnitzler JP (2010) Abiotic stresses and induced BVOCs. Trends Plant Sci 15:154-166. https://doi.org/10.1016/j.tplants. 2009.12.006 
Lüpke M, Leuchner M, Steinbrecher R, Menzel A (2017) Quantification of monoterpene emission sources of a conifer species in response to experimental drought. AoB Plants 9:plx045. https:// doi.org/10.1093/aobpla/plx045

Mackay DS, Savoy PR, Grossiord C, Tai X, Pleban JR, Wang DR, McDowell NG, Adams HD, Sperry JS (2020) Conifers depend on established roots during drought: results from a coupled model of carbon allocation and hydraulics. New Phytol 225:679-692. https://doi.org/10.1111/nph.16043

Manninen AM, Tarhanen S, Vuorinen M, Kainulainen P (2002) Comparing the variation of needle and wood terpenoids in Scots pine provenances. J Chem Ecol 28:211-228. https://doi.org/10.1023/A: 1013579222600

Mattson J, Haack RA (1987) The role of drought in outbreaks of planteating insects. Bioscience 37:110-118. https://doi.org/10.2307/ 1310365

McDowell NG, Beerling DJ, Breshears DD, Fisher RA, Raffa KF, Stitt M (2011) The interdependence of mechanisms underlying climate-driven vegetation mortality. Trends Ecol Evol 26:523-532. https://doi.org/10.1016/j.tree.2011.06.003

McDowell NG, Fisher RA, Xu C, Domec JC, Holtta T, Mackay DS, Sperry JS, Boutz A, Dickman L, Gehres N, Limousin JM (2013) Evaluating theories of drought-induced vegetation mortality using a multimodel-experiment framework. New Phytol 22:304-321. https://doi.org/10.1111/nph.12465

McDowell NG, Williams AP, Xu C, Pockman WT, Dickman LT, Sevanto S, Pangle R, Limousin J, Plaut J, Mackay DS, Ogee J, Domec JC, Allen CD, Fisher RA, Jiang X (2016) Multi-scale predictions of massive conifer mortality due to chronic temperature rise. Nat Clim Change 6:295-300. https://doi.org/10.1038/nclim ate 2873

McDowell NG, Grossiord C, Adams HD, Pinzón-Navarro S, Mackay DS, Breshears DD, Allen CD, Borrego I, Dickman LT, Collins A, Gaylord M (2019) Mechanisms of a coniferous woodland persistence under drought and heat. Environ Res Lett 14:045014. https:// doi.org/10.1088/1748-9326/ab0921

Moran E, Lauder J, Musser C, Stathos A, Shu M (2017) The genetics of drought tolerance in conifers. New Phytol 216:1034-1048. https:// doi.org/10.1111/nph.14774

Netherer S, Matthews B, Katzensteiner K, Blackwell E, Henschke P, Hietz P, Pennerstorfer J, Rosner S, Kikuta S, Schume H, Schopf A (2015) Do water-limiting conditions predispose Norway spruce to bark beetle attack? New Phytol 205:1128-1141. https://doi.org/ 10.1111/nph.13166

Niinemets $\ddot{U}$ (2017) Uncovering the hidden facets of drought stress: secondary metabolites make the difference. Tree Physiol 36:129 132. https://doi.org/10.1093/treephys/tpv128

Nowak M, Kleinwaechter M, Manderscheid R, Weigel HJ, Selmar D (2010) Drought stress increases the accumulation of monoterpenes in sage (Salvia officinalis), an effect that is compensated by elevated carbon dioxide concentration. J Appl Bot Food Qual 83:133-136

O’Brien MJ, Leuzinger S, Philipson CD, Tay J, Hector A (2014) Drought survival of tropical tree seedlings enhanced by non-structural carbohydrate levels. Nat Clim Change 4:710-714. https://doi. org/10.1038/nclimate2281

O'Brien MJ, Burslem DF, Caduff A, Tay J, Hector A (2015) Contrasting nonstructural carbohydrate dynamics of tropical tree seedlings under water deficit and variability. New Phytol 205:1083-1094. https://doi.org/10.1111/nph.13134

Oksanen J, Guillaume F, Friendly M, Kindt R, Legendre P, McGlinn D, Minchin PR, O'Hara RB, Simpson L, Solymos P, Stevens MHH, Szoecs Eduard, Wagner H (2019) vegan: community ecology package. R package version 2.5-6. https://CRAN.R-project.org/ package $=$ vegan
Pangle RE, Hill JP, Plaut JA, Yepez EA, Elliot JR, Gehres N, Mcdowell NG, Pockman WT (2012) Methodology and performance of a rainfall manipulation experiment in a piñon-juniper woodland. Ecosphere 3:1-20. https://doi.org/10.1890/ES11-00369.1

Peñuelas J, Munné-Bosch S (2005) Isoprenoids: an evolutionary pool for photoprotection. Trends Plant Sci 10:166-169. https://doi.org/ 10.1016/j.tplants.2005.02.005

Quentin AG, Pinkard EA, Ryan MG, Tissue DT, Baggett LS, Adams HD, Maillard P, Marchand J, Landhäusser SM, Lacointe A, Gibon Y (2015) Non-structural carbohydrates in woody plants compared among laboratories. Tree Physiol 35:1146-1165. https://doi.org/ 10.1093/treephys/tpv073

R Core Team (2018) R: a language and environment for statistical computing. R Foundation for Statistical Computing, Vienna, Austria. Available online at https://www.R-project.org/

Radwan A, Kleinwächter M, Selmar D (2017) Impact of drought stress on specialised metabolism: biosynthesis and the expression of monoterpene synthases in sage (Salvia officinalis). Phytochemistry 141:20-26. https://doi.org/10.1016/j.phytochem.2017.05.005

Raffa KF, Berryman AA (1983) The role of host plant resistance in the colonization behavior and ecology of bark beetles (Coleoptera: Scolytidae). Ecol Monogr 53:27-49. https://doi.org/10.2307/ 1942586

Raffa KF, Berryman AA (1987) Interacting selective pressures in conifer-bark beetle systems: a basis for reciprocal adaptations? Am Nat 129:234-262. https://doi.org/10.1086/284633

Raffa KF, Aukema BH, Erbilgin N, Klepzig KD, Wallin KF (2005) Interactions among conifer terpenoids and bark beetles across multiple levels of scale: an attempt to understand links between population patterns and physiological processes. Recent Adv Phytochem 39:79-118

Raffa KF, Aukema BH, Bentz BJ, Carroll AL, Hicke JA, Turner MG, Romme WH (2008) Cross-scale drivers of natural disturbances prone to anthropogenic amplification: the dynamics of bark beetle eruptions. Bioscience 58:501. https://doi.org/10.1641/B580607

Raffa KF, Powell EN, Townsend PA (2013) Temperature-driven range expansion of an irruptive insect heightened by weakly coevolved plant defenses. Proc Natl Acad Sci USA 110:2193-2198. https:// doi.org/10.1073/pnas.1216666110

Rosas T, Galiano L, Ogaya R, Penuelas J, Martinez-Vilalta J (2013) Dynamics of non-structural carbohydrates in three Mediterranean woody species following long-term experimental drought. Front Plant Sci 4:400. https://doi.org/10.3389/fpls.2013.00400

Roth M, Hussain A, Cale JA, Erbilgin N (2018) Successful colonization of lodgepole pine trees by mountain pine beetle increased monoterpene production and exhausted carbohydrate reserves. J Chem Ecol 44:209-214. https://doi.org/10.1007/ s10886-017-0922-0

Ryan MG, Sapes G, Sala A, Hood S (2015) Tree physiology and bark beetles. New Phytol 205:955-957. https://doi.org/10.1111/nph. 13256

Sancho-Knapik D, Sanz MÁ, Peguero-Pina JJ, Niinemets Ü, Gil-Pelegrín E (2017) Changes of secondary metabolites in Pinus sylvestris L. needles under increasing soil water deficit. Ann for Sci 74:24. https://doi.org/10.1007/s13595-017-0620-7

Sevanto S (2014) Phloem transport and drought. J Exp Bot 65:17511759. https://doi.org/10.1093/jxb/ert467

Sevanto S, Dickman LT (2015) Where does the carbon go?-plant carbon allocation under climate change. Tree Physiol 35:581-584. https://doi.org/10.1093/treephys/tpv059

Sevanto S, McDowell NG, Dickman LT, Pangle R, Pockman WT (2014) How do trees die? A test of the hydraulic failure and carbon starvation hypotheses. Plant Cell Environ 37:153-161. https:// doi.org/10.1111/pce.12141

Sjödin K, Persson M, Borg-Karlson AK, Norin T (1996) Enantiomeric compositions of monoterpene hydrocarbons in different tissues of 
four individuals of Pinus sylvestris. Phytochemistry 41:439-445. https://doi.org/10.1016/0031-9422(95)00652-4

Sjödin K, Persson M, Fäldt J, Ekberg I, Borg-Karlson AK (2000) Occurrence and correlations of monoterpene hydrocarbon enantiomers in Pinus sylvestris and Picea abies. J Chem Ecol 26:17011720. https://doi.org/10.1023/A:1005547131427

Tittiger C, Blomquist GJ (2016) Pheromone production in pine bark beetles. Adv Insect Physiol 50:235-263. https://doi.org/10.1016/ bs.aiip.2016.02.002

Trowbridge AM, Daly RW, Helmig D, Stoy PC, Monson RK (2014) Herbivory and climate interact serially to control monoterpene emissions from pinyon pine forests. Ecology 95:1591-1603. https://doi.org/10.1890/13-0989.1

Trowbridge AM, Bowers MD, Monson RK (2016) Conifer monoterpene chemistry during an outbreak enhances consumption and immune response of an eruptive folivore. J Chem Ecol 42:12811292. https://doi.org/10.1007/s10886-016-0797-5

Trowbridge AM, Stoy PC, Adams HD, Law DJ, Breshears DD, Helmig D, Monson RK (2019) Drought supersedes warming in determining volatile and tissue defenses of piñon pine (Pinus edulis). Environ Res Lett 14:065006. https://doi.org/10.1088/ 1748-9326/ab1493

Turtola S, Manninen A-M, Rikala R, Kainulainen P (2003) Drought stress alters the concentration of wood terpenoids in Scots Pine and Norway Spruce seedlings. J Chem Ecol 29:1981-1995. https://doi.org/10.1023/A:1025674116183

Wiley E, Rogers BJ, Hodgkinson R, Landhäusser SM (2016) Nonstructural carbohydrate dynamics of lodgepole pine dying from mountain pine beetle attack. New Phytol 209:550-562. https:// doi.org/10.1111/nph.13603

Woodruff DR (2014) The impacts of water stress on phloem transport in Douglas-fir trees. Tree Physiol 34:5-14. https://doi.org/10. 1093/treephys/tpt106

Züst T, Agrawal AA (2017) Trade-offs between plant growth and defense against insect herbivory: an emerging mechanistic synthesis. Annu Rev Plant Biol 68:513-534. https://doi.org/10.1146/ annurev-arplant-042916-040856 